\title{
PRICE LEVEL DETERMINACY WITHOUT \\ CONTROL OF A MONETARY AGGREGATE
}

Michael Woodford

Working Paper No. 5204

\section{NATIONAL BUREAU OF ECONOMIC RESEARCH 1050 Massachusetts Avenue \\ Cambridge, MA 02138 \\ August 1995}

Revision of a paper prepared for the Carnegie-Rochester Conference on Public Policy, CarnegieMellon University, November 18-19, 1994. I would like to thank Carl Christ, John Coleman, Michael Dotsey, Bill Dupor, Herschel Grossman, Bob Hall, Nobu Kiyotaki, Randy Kroszner, Robert Lucas, Allan Meltzer, Bennett McCallum, Casey Mulligan, Chris Phelan, Julio Rotemberg, and Anna Schwartz, Richard Sweeney, and especially Rao Aiyagari for helpful comments on earlier drafts, and the National Science Foundation for research support. This paper is part of NBER's research programs in Economic Fluctuations and Monetary Economics. Any opinions expressed are those of the author and not those of the National Bureau of Economic Research.

() 1995 by Michael Woodford. All rights reserved. Short sections of text, not to exceed two paragraphs, may be quoted without explicit permission provided that full credit, including () notice, is given to the source. 


\title{
PRICE LEVEL DETERMINACY WITHOUT \\ CONTROL OF A MONETARY AGGREGATE
}

\begin{abstract}
It is shown that the price level remains determinate even in the case of two kinds of radical money supply endogeneity -- an interest rate peg by the central bank, and a "free banking" regime -- that are commonly supposed to imply loss of control of the price level. Price level determination under such regimes can be understood in terms of a "fiscal theory of the price level," according to which the equilibrium price level is that level that makes the real value of nominally denominated government liabilities equal to the present value of expected future government budget surpluses. The application of the fiscal theory of the price level to exogenous-money regimes is sketched as well.
\end{abstract}

Michael Woodford

Department of Economics

Princeton University Princeton, NJ 08544 and NBER 
For a long time, the conventional account of the determination of the general level of prices in an economy has been given by the quantity theory of money. According to this view, the pattern of real activity in an economy implies a certain desired level of real money balances; then, given the nominal money supply (generally supposed to be determined more or less directly by the central bank's monetary policy), the price level is determined as the unique level of prices that will make the purchasing power of the money supply equal the desired level of real balances.

Such an account leads quickly to the conclusion that it is important for monetary policy to be formulated so as to control the quantity of money in circulation. For, it is argued, a central bank policy of supplying "as much money as trade requires" would mean a nominal money supply that varies in proportion with whatever the level of prices may be (as it is the demand for real balances that is determined by other factors), while this price level is itself determined by nothing other than that money supply -- so that both the money supply and the level of prices would become completely indeterminate. Policies that target nominal interest rates, rather than targeting a monetary aggregate and leaving interest rates to be determined in the money markets, have in particular been criticized on this ground (Patinkin, 1961; 1965, pp. 308-9; Sargent and Wallace, 1975). The quantity-theoretic account similarly leads to the conclusion that it is important, for the possibility of control of the path of the price level (and of aggregate demand more generally) that there continue to be a sharp distinction between "monetary" and "non-monetary" financial assets, so that the nominal value of the former can be measured and controlled. This has often resulted in opposition, on the part of quantity theorists, toward financial innovation or deregulation of the activities of financial intermediaries, when this would allow the creation of money substitutes. ${ }^{1}$

I wish to challenge both of these conclusions. It is of particular relevance to reevaluate them now, for the recent rapid pace of financial innovation and deregulation have led to increasing questioning of the practical relevance of traditional measures of the money supply. Indeed, those nations, such as the United States and Great Britain, that had in the late 1970's embraced monetary targeting as an explicit approach to the conduct of monetary policy, had by the late 1980's ceased even to pay lip service to targets for the growth of monetary aggregates, as a result of a generally conceded breakdown of the empirical relationship between popular aggregates and the level of nominal spending in those countries. Thus it is of considerable importance to ask whether control of a monetary aggregate remains an essential element of a well-formulated monetary policy (Benjamin Friedman, 1988). Similarly, the question whether the price level would be determinate in a world in

\footnotetext{
${ }^{1}$ Perhaps the classic example is the support of the "Currency School" authors for Peel's Bank Act of 1844, preventing the issuance of bank notes by private and joint-stock banks, as well as regulating the note issue of the Bank of England (Fetter, 1965, chap. VI). An example after the fact would be Milton Friedman's (1959, p. 21) endorsement of the feature of the U.S. National Banking Act that taxed state bank notes out of existence. (Note however that Friedman has recently written more favorably of deregulation of financial intermediaries; see Friedman and Schwartz, 1986.) For a recent example of concern about the consequences of present trends toward financial innovation and deregulation for monetary control, see Cagan (1986).
} 
which private intermediaries created perfect substitutes for official money is hardly of mere academic interest, given the current pace of financial innovation, and given the clear private incentives that exist for the circumvention of central bank attempts to limit the quantity of money. The extent to which it is in fact important to direct the efforts of government regulators toward impeding the inevitable is a question of practical significance.

I shall argue that these conventional views about the requirements for a determinate price level are wrong. Understanding why they are wrong requires that one understand the role of government fiscal policy in price level determination. Quantity-theoretic accounts price level determination rely upon a particular set of requirements for equilibrium. I do not wish to deny the role of these requirements, ${ }^{2}$ so much as to question whether they suffice to determine the equilibrium price level. Often, I shall argue, they do not. But when they do not, one should not conclude that the equilibrium price level is indeterminate, and so free to respond to arbitrary, self-fulfilling changes in expectations. Instead, it is often simply a matter of the equilibrium conditions stressed in quantity-theoretic accounts being incomplete. When one takes into account the consequences for the price level of the government's fiscal policy rule as well, the equilibrium price level may be uniquely determined after all. This is true in a series of examples presented below.

Fiscal policy affects the equilibrium price level for a simple reason. An increase in the price level reduces the real value of the net (outside) assets of the private sector, or equivalently, the real value of net government liabilities, assuming that there exists a positive quantity of nominal government liabilities (including, but not limited to, the monetary base). This reduction of private sector wealth naturally reduces private sector demand for goods and services, through a straightforward wealth effect. As a result, there will typically be only one price level that results in aggregate demand that equals aggregate supply. Changes in expectations regarding future government budgets have similar wealth effects, that require an offsetting change in the price level in order for equilibrium to be maintained.

One thus arrives at a theory of price level determination in which government fiscal policy plays the crucial role, both because the effects of price level changes upon aggregate demand depend upon the size of the outstanding nominal government debt, and because of the wealth effects of expected future government budgets. Furthermore, the effects of fiscal policy changes on the equilibrium price level are largely independent of any changes in the path of the money supply that might be associated with them.

This channel for effects of the price level on aggregate demand continues to be operative even if the central bank varies the money supply in response to a price level change so as to keep real

\footnotetext{
${ }^{2} \mathrm{My}$ point is therefore quite different from that made in criticisms of quantity-theoretic reasoning that deny the existence of a well-defined demand for money, such as Kaldor (1982). On the other hand, the theory presented here is one in which such a relation is no longer crucial to price level determination. Thus it is well-suited to the analysis of price level determination in a world in which such relations have ceased to be stable.
} 
balances invariant (as must occur, according to the conventional analysis, under a policy that pegs the nominal interest rate); for open market operations to increase the money supply, if conducted in the market for non-indexed government debt, do not change the nominal value of total government liabilities. Similarly, it continues to be operative even if the government's "monetary" liabilities are perfect substitutes for other kinds of assets -- because no change in the rate of return on any of those assets is required in order for the reduction in private sector wealth to affect aggregate demand. Thus, contrary to what a simple quantity-theoretic (or IS-LM) analysis would suggest, the mere fact that the money supply is allowed to freely vary in response to changes in money demand does not eliminate all mechanisms through which changes in the price level affect aggregate demand. And as a result, such a regime need not result in price level indeterminacy.

The fact that an additional equilibrium condition involving fiscal variables is needed for price level determination under an endogenous-money regime is actually not a special feature of such regimes. Even under regimes that involve exogenously fixing the path of a monetary aggregate, the equilibrium conditions considered in quantity-theoretic accounts often fail to uniquely determine an equilibrium price level; and thus under these regimes as well, there is room for fiscal policy to determine the price level. Indeed, the fiscal theory of the price level studied here seems to provide a useful way of thinking about price level determination regardless of the character of monetary policy, although its usefulness becomes especially apparent in the case of endogenous-money regimes, where the quantity-theoretic approach is completely helpless.

In one special case, the fiscal considerations referred to above fail to play any role in price level determination. This is the case of what I call below a "Ricardian" policy regime. In this special case, the wealth effect of a price level change does not exist (in the kind of simple, aggregative model considered here). As a result, only the factors stressed in quantity-theoretic accounts play any role in price level determination. However, in such a case, the equilibrium price level is typically not uniquely determined, regardless of the form of the monetary policy rule. The indeterminacy is thus arguably better attributed to the "Ricardian" fiscal policy than to any failure to control the money supply.

The paper proceeds as follows. In section 1, I introduce the basic analytical framework within which the paper's formal results are derived, and discuss in general terms the role of fiscal policy in price level determination. In section 2, the fiscal theory of the price level is further developed in the context of a specific class of policy regimes in which the central bank exogenously fixes the path of the money supply. It is shown that despite this the specification of fiscal variables has a crucial effect upon the price level, and even that to a certain extent the path of the money supply does not matter, except insofar as alternative paths for the money supply have fiscal consequences. In section 3, I discuss how it is possible for changes in the government budget to have 
wealth effects, and hence to affect price level determination. The basic point is that "Ricardian equivalence" need not obtain, except in the case of a particular, restrictive class of policy regimes.

I then consider the possibility of price level determinacy in the case of an endogenous money supply, in the context of the model thus developed. In section 4, I consider a variety of pure interest rate pegs, and show that a unique perfect foresight equilibrium price level can easily exist. In such regimes, fiscal policy is shown to play a crucial role in price level determination. In section 5 , the model is modified to allow for private issuance of liabilities that can serve as substitutes for money in the transactions technology. In this case, even if monetary policy is formulated in terms of a target path for the (government-issued) money supply, variations in the path of the money supply have no effect upon equilibrium, other than through their fiscal implications (i.e., their effects upon seignorage revenues). Nonetheless, I show that for a wide class of such policies there exists a unique perfect foresight equilibrium path for the price level. Again this can easily be understood in terms of the fiscal theory of the price level. Section 6 concludes.

\section{A Fiscal Theory of the Price Level}

\section{A. A Simple Framework}

In this section I illustrate how a fiscal theory of price level determination is possible, in the context of a simple representative-household model of a monetary economy, of the kind introduced by Sidrauski (1967) and Brock $(1974,1975)$. The use of this model is intended to demonstrate that the mechanism emphasized here does not depend upon ignoring the existence of "liquidity preference" as conventionally conceived. ${ }^{3}$ The economy is made up of identical infinite-lived households, each of which seeks to maximize its lifetime utility

$$
\sum_{i=0}^{\infty} \beta^{\imath} U\left(c_{t}, M_{t} / p_{t}\right)
$$

where $0<\beta<1$ is a constant discount factor, and the period utility function $U(c, m)$ is concave and increasing in both arguments. Here $c_{t}$ denotes the household's consumption in period $t$ of the single consumption good, $p_{t}$ is the money price of that good, and $M_{t}$ denotes the (nominal) money balances held by the household at the end of period $t$.

\footnotetext{
${ }^{3}$ The analysis here is thus not subject to the criticism that McCallum (1986, p. 25) directs against the attempt of Sargent and Wallace (1982) to rehabilitate the "real bills doctrine" in the context of an overlapping generations model, namely, that because "every asset in the model must have the same monetary status ... it becomes impossible to carry out any analysis that involves a distinction between money and non-monetary paper assets." The use of a representativehousehold model also makes it clear that the failure of Ricardian equivalence -- that is of considerable importance for the results obtained here, as explained in the next section - is not due to the familiar reasons for failure of Ricardian equivalence in overlapping generations models. The results here are thus not subject to the criticism of Barro (1974) against the use of overlapping generations models to make such a point.
} 
The appearance of real money balances as an argument of the utility function is, as usual, to be understood as representing the convenience value of carrying out transactions using money; the underlying reasons why this is so are not modeled. To be precise, I will interpret $M_{t}$ as referring to a household's direct or indirect holdings of the monetary base - that is, as a sum of currency holdings and of the reserves held on behalf of that household by intermediaries (not explicitly modeled) with which the household maintains deposits, with the household's optimizing choice of how much to hold as currency and how much as deposits at intermediaries subject to reserve requirements having already been substituted out of the indirect utility function $u(c, m)$. This simplification (treating households as directly demanding the monetary base) is possible if one assumes that, owing to competition between intermediaries, the interest foregone on each dollar of the monetary base held by a household is the same, regardless of whether it is held directly (as currency) or indirectly (as a deposit), or indeed regardless of which of several types of deposit it might be (Patinkin, 1969).

For simplicity, I will consider only deterministic monetary/fiscal policies, and likewise only deterministic, or perfect foresight, equilibria. As a result, it suffices to consider trading in a single kind of financial asset each period in addition to money, that I will assume to be a market for oneperiod nominal bonds. ${ }^{4}$ If one likes, one may think of this as the market for government bonds, although the budget constraint proposed below does not require a household to hold a non-negative quantity of the bonds, so that a household can be an issuer of bonds. Let $R^{b}{ }_{t}$ be the gross nominal return on bonds held from period $t$ to period $t+1$; that is, bonds costing one dollar at date $t$ can be redeemed for $R^{b}{ }_{t}$ dollars at date $t+1$. Similarly, let $R^{m_{t}}$ be the gross nominal return on money -- i.e., on the monetary base. (Under current U.S. institutional arrangements, of course, $R^{m_{t}}=1$ at all times; but we need not assume this, especially if we wish to consider the possibilities for monetary policy in a "cashless economy" of the kind to which we arguably are headed.) Then a household chooses

in period $t$ a level of consumption $c_{t}$, end-of-period money holdings $M_{t}$ and end-of-period bond holdings $B_{t}$, subject to the budget constraint

$$
p_{t} c_{t}+M_{t}+B_{t} \leq W_{t}+p_{t} y_{t}-T_{t}
$$

where $W_{t}$ denotes the nominal value of beginning-of-period wealth, $y_{t}$ denotes real income (treated here as a quantity of consumption goods with which the household is endowed), and $T_{t}$ denotes the nominal value of net taxes paid in period $t$ (treated here as lump-sum). Nominal wealth in the following period then follows from the household's portfolio decision according to the law

$$
W_{t+1}=M_{t} R_{t}^{m}+B_{t} R_{t}^{b}
$$

The household's consumption/portfolio choice in period $t$ must be such that

\footnotetext{
${ }^{4}$ The question of what kind of financial instruments are traded -- indexed or not, of what maturity, etc. .- does still matter for one point, and that relates to the way in which initial private sector claims on the government are specified. Alternative assumptions in this regard are taken up below in section 4 .
} 
$c_{t} M_{t} \geq 0$. (If I allowed households to issue money, there would be no possibility of an equilibrium in which the rates of return on money and bonds differed; and this would not allow me to discuss interest-rate pegging by the central bank in any meaningful sense. Privately issued money subsitutes are considered in the next section.) There is no similar non-negativity constraint on $B_{b}$ thus borrowing is allowed. But each household is constrained by a borrowing limit, i.e., a lower bound upon the value of $W_{t+1}$ implied by its portfolio. Specifically, the household must begin each period with a debt no larger than the following:

$$
W_{t} \geq-\sum_{j=0}^{\infty} \frac{p_{t+j} y_{t+j}-T_{t+j}}{\Pi_{s=0}^{j-1} R_{t+s}^{b}}
$$

This debt limit is the tightest limit with the property that any debt that can be repaid in finite time is permissible. ${ }^{5}$ (The rate of return on bonds is the relevant one in defining such a limit, because of the constraint that $M_{t+s} \geq 0$.) Note that some limit on borrowing is necessary, in order for there to be a well-defined budget set for the household (otherwise, Ponzi schemes would be possible). The borrowing limit (1.3) is convenient, because it cannot ever bind unless the household intends never to consume or hold any money at any later date; thus standard boundary conditions on the utility function suffice to ensure that in equilibrium (1.3) will not bind, just as with the non-negativity constraints on $c_{t}$ and $M_{t}$.

A household, then, chooses lifetime consumption/portfolio plans $\left\{c_{t}, M_{t}, B_{t}\right\}$, satisfying (1.1), (1.2) and the non-negativity constraints for all $t \geq 0$, and (1.3) for all $t \geq 1$, given an initial wealth $W_{Q}$ the price and interest rate sequences $\left\{p_{b} R^{m_{b}} R^{b} t\right.$, and the income and net tax sequences $\left\{y_{t}, T_{t}\right\}$. These sequences describe a perfect foresight equilibrium if the money balances $M_{t}$ demanded by the representative household each period equal the money supplied by the government, the bonds $B_{t}$ demanded similarly equal the quantity of government bonds issued, and

$$
c_{t}+g_{t}=y_{t}
$$

where $g_{t}$ denotes government purchases of the good in period $t$.

The government's monetary/fiscal policy regime specifies some four of the sequences $\left\{g_{t} T_{t}\right.$ $\left.R^{m_{t}} R_{t}^{b_{t}} M_{t} B_{t}\right\}$, possibly as functions of the others or of other state variables such as $\left\{p_{t}\right\}$. Only four of these sequences can be independently chosen by government policy. This is because one is implied by the others, through the government's financing constraint

$$
p_{t} g_{t}=T_{t}+\left(M_{t}-M_{t-1} R_{t-1}^{m}\right)+\left(B_{t}-B_{t-1} R_{t-1}^{b}\right)
$$

that must be satisfied each period. (In period zero, the government starts with initial outstanding liabilities $M_{-1} R^{m} m_{-1}+B_{-1} R_{-1}^{b}=W_{0}$.) Furthermore, the government cannot exogenously specify both the price of bonds in terms of money, and the quantities of each that will be outstanding; if it

5 This corresponds to the concept of "borrowing limited only by one's future endowment", defined in a more general context in Santos and Woodford (1993). Note that the borrowing limit could equivalently be expressed as a lower bound on the value of end-of-period wealth. If the infinite sum in (1.3) does not converge, it is to be interpreted as meaning lim $\sup T \rightarrow \infty_{j=0} \Sigma_{\mathrm{t}, t+j}$, where $Z_{\mathrm{t}, t+j}$ denotes the present value at $t$ of income net of taxes in period $t+j$. 
determines the quantities that it supplies of each, it must allow the price of bonds to be determined in the market, while if it determines the relative price (by fixing $R^{m_{t}}$ and $R^{b} t$ ), it must allow the private sector to determine the portfolio shares that it desires to allocate to the two assets. Thus government policy can exogenously specify at most three of the variables $\left\{R^{m_{t}} R^{b}{ }_{t} M_{t} B_{t}\right\}^{6}$

For example, in the quantity-theoretic tradition, it is common to analyze policy regimes in which the government exogenously specifies the path of the money supply $\left\{M_{t}\right\}$, and in which there is assumed to be no government borrowing. A complete description of such a monetary-fiscal policy regime would involve exogenous specification of the sequences $\left.g_{t}, R^{m_{t}} M_{t} B_{t}\right\}$, with $\left\{T_{t}\right\}$ then being implied by (1.5), and $\left\{R_{t}^{b}\right\}$ being determined in the bond market. (The specification generally assumes $R^{m_{t}}=1, B_{t}=0$ for all $t$, and often specifies $g_{t}=0$ for all $t$ as well.) In the next section, I consider instead an alternative type of regime, in which $\left\{g_{t} R^{m_{D}} M_{t}\right\}$ are again exogenously specified, but $\left\{T_{t}\right\}$ is determined by a feedback rule that involves the endogenous variables $\left\{p_{t}, R^{b} t\right\}$, and $\left\{B_{t}\right\}$ is then implied by (1.5). As yet another alternative, one might consider a pure interest rate peg, in which monetary policy exogenously specifies the variables $\left\{R^{m_{t}} R^{b} t\right\}$, while allowing the composition of government liabilities to be determined by the market. If fiscal policy specifies the time paths of government purchases and tax collections, the evolution of total government liabilities is then implied by (1.5), but neither $\left\{M_{t}\right\}$ nor $\left\{B_{t}\right\}$ individually is fixed by government policy. Several policy regimes of this kind are analyzed in section 5 .

Without further specifying the policy regime at this point, let us consider the requirements for perfect foresight equilibrium in this model. First of all, it is easily shown ${ }^{7}$ that the budget constraints stated above are equivalent to a requirement that the lifetime consumption and moneyholding plans $\left\{c_{t}, M_{t}\right\}$ satisfy the non-negativity constraints for all $t \geq 0$, and the present-value budget constraint ${ }^{8}$

$$
\sum_{t=0}^{\infty} \frac{p_{t} c_{t}+\Delta_{t} M_{t}}{\Pi_{s=0}^{t-1} R_{s}^{b}} \leq \sum_{t=0}^{\infty} \frac{p_{t} y_{t}-T_{t}}{\Pi_{s=0}^{t-1} R_{s}^{b}}+W_{0}
$$

given the initial wealth $W_{0}$, where $\Delta_{t}=\left(R^{b}{ }_{t} R^{m} t\right) / R^{b} t$. Note that constraint (1.6) is of the same kind as for a non-monetary economy, except that the interest-rate differential $\Delta_{t}$ appears as the "price" of holding money (due to foregone interest earnings). I assume boundary conditions on utility that imply that the non-negativity constraints do not bind. Then the plans $\left\{c_{t}, M_{t}\right\}$ are optimal for the household if and only if the first-order conditions

\footnotetext{
${ }^{6}$ I do not attempt here to give a complete characterization of the class of logically possible policy regimes, as I will in any event not offer any results about existence or uniqueness of equilibrium that apply to all policy regimes. A number of special cases are defined more completely in subsequent sections.

${ }^{7}$ See the analysis of a similar system of budget constraints in Woodford (1994).

${ }^{8}$ The technical definition of the infinite sum on the right hand side of (1.6) is as in footnote 5 . The sum on the left-hand side is necessarily well-defined, because of the non-negativity of each term in the sum.
} 


$$
\begin{aligned}
& \frac{u_{m}\left(c_{t}, m_{t}\right)}{u_{c}\left(c_{t}, m_{t}\right)}=\Delta_{t} \\
& u_{c}\left(c_{t}, m_{t}\right)=\beta\left(1+r_{t}^{b}\right) u_{c}\left(c_{t+1}, m_{t+1}\right)
\end{aligned}
$$

hold for all $t \geq 0$, where $m_{t}=M_{V} p_{t}$ represents real balances and $r_{t} b_{t} R_{t}\left(p_{t} / p_{t+1}\right)-1$ is the real rate of return on bonds, and the present-value budget constraint (1.6) holds with equality. It is also necessary for the existence of an optimal plan that both the left- and right-hand sides of (1.6) be finite. For if the right-hand side were to be infinite, (1.6) would represent no constraint upon the attainable level of consumption, so that no consumption plan could possibly be the best.

If consumption and real balances are both normal goods, $u_{m} / u_{c}$ is increasing in $c$ and decreasing in $m$, from which it follows that $(1.7 \mathrm{a})$ can be inverted to yield

$$
m_{t}=L\left(c_{t}, \Delta_{t}\right)
$$

where the liquidity preference function $L$ is increasing in $c$ and decreasing in $\Delta$.. Substituting (1.4) into (1.7a) then yields the equilibrium condition

$$
m_{t}=L\left(y_{t}-g_{t}, \Delta_{t}\right)
$$

This is a standard "LM equation", except that money demand is assumed to depend only upon private, as opposed to government, purchases. Substituting (1.4) into (1.7b) similarly yields

$$
\lambda\left(y_{t}-g_{t}, \Delta_{t}\right)=\beta\left(1+r_{t}^{b}\right) \lambda\left(y_{t+1}-g_{t+1}, \Delta_{t+1}\right)
$$

where $\lambda(c, \Delta)=u_{c}(c, L(c, \Delta))$. This is essentially an intertemporal-optimization-based version of the Hicksian "IS equation". Finally, substituting (1.4) into (1.6), and requiring that the budget constraint hold with equality, yields 9

$$
\frac{W_{0}}{p_{0}}=\sum_{t=0}^{\infty} \frac{\left(\tau_{t}-g_{t}\right)+\Delta_{t} m_{t}}{\Pi_{s=0}^{t-1}\left(1+r_{s}^{b}\right)}
$$

where $\tau_{t}=T_{t} / p_{t}$ represents real tax revenues each period. Equation (1.9) states that a present-value budget constraint must hold for the government as well, in equilibrium, owing to the fact that optimizing private households plan to exhaust their own budget constraints. According to this constraint, the present value of future primary government budget surpluses must equal the value of current net government liabilities; government "revenues" in this calculation include a term $\Delta_{t} m_{t}$, indicating interest savings on the government's "monetary" liabilities. ${ }^{10}$

A perfect foresight equilibrium is then a collection of sequences $\left\{p_{t}, R^{m_{t}} R_{t}^{b} M_{t} g_{t} T_{t}\right\}$ that are consistent with the monetary-fiscal policy regime, that satisfy $(1.8 \mathrm{a})$ and $(1.8 \mathrm{~b})$ for each $t$,

\footnotetext{
${ }^{9}$ If the infinite sum in (1.9) does not converge, it is to be interpreted as meaning $\lim \inf _{T \rightarrow \infty} \Sigma_{j=0} T Y_{t, t+j}$, where $Y_{t}$, $t+j$ denotes the present value at $t$ of the primary government surplus in period $t+j$, counting interest savings. Note that it is a requirement of equilibrium that the $\lim$ inf of this series be finite, though the limit need not exist. Note also that the present value of the $\Delta m$ terms is necessarily a well-defined, finite sum, because the left-hand side of (1.6) must be well-defined and finite; but the $(\tau-g)$ terms need not have a well-defined present value, in the absence of further assumptions.

${ }^{10}$ Sweeney (1988, pp. 136-137) describes these additional terms as the government's income from "rent[ing] the use of its fiat dollars to the public".
} 
given the exogenous process $\left\{y_{t}\right\}$, and that satisfy (1.9) given $W_{0}$. (The sequences must also be such that the infinite sum on the right hand side of (1.6) is finite.) Since the monetary-fiscal policy regime determines four of these sequences (or at any rate, four independent relations involving them each period), we have a total of six independent equilibrium conditions to determine these six variables.

Similar reasoning as in the derivation of (1.9) allows one to show that at each date $t$ the real value of net government liabilities must satisfy

$$
\frac{W_{t}}{p_{t}}=\sum_{s=t}^{\infty} \frac{\left(\tau_{s}-g_{s}\right)+\Delta_{s} m_{s}}{\Pi_{j=t}^{s-1}\left(1+r_{j}^{b}\right)}
$$

This can be viewed as an equilibrium condition that determines the price level $p_{t}$ at date $t$, given the predetermined nominal value of net government liabilities $W_{t}$ and given expectations at date $t$ regarding the current and future values of the real quantities and relative prices that enter the expression on the right-hand side of (1.10). The variable $W_{t}$ is determined by past government budget surpluses, following the law of motion

$$
W_{t+1}=R_{t}^{b}\left[W_{t}+p_{t}\left(g_{t}-\tau_{t}-\Delta_{t} m_{t}\right)\right]
$$

obtained by substituting (1.5) into (1.2). A perfect foresight equilibrium can then equivalently be defined as a collection of sequences $\left\{p_{b} R^{m_{b}} R^{b}{ }_{b} M_{t} W_{t} g_{t} T_{t}\right\}$ that are consistent with the monetary-fiscal policy regime, that make the right hand side of (1.6) finite, and that satisfy (1.8a), (1.8b) and (1.10) for each $t$, given the initial condition $W_{0}$. (One need not impose (1.11) as an additional equilibrium condition, as it is just a quasi-differenced form of (1.10).)

Condition (1.10) is not implied by (1.11) alone, but it is equivalent to (1.11) together with the "transversality condition"11

$$
\lim _{T \rightarrow \infty} \frac{W_{T}}{\Pi_{s=0}^{T-1} R_{s}^{b}}=0 .
$$

So a perfect foresight equilibrium can also equivalently be defined as a collection of sequences $\left\{p_{t}\right.$, $R^{m} m_{t} R_{t}^{b}, M_{t}, W_{t}, g_{t}, T_{t}$ that are consistent with the monetary-fiscal policy regime, that make the right hand side of (1.6) finite, that satisfy (1.8a), (1.8b) and (1.11) for each $t$, and that satisfy (1.12), given the initial condition $W_{0}$.

\section{B. Fiscal Policy and the Price Level}

This system of equilibrium conditions has a relatively familiar form, and indeed I have chosen a framework that incorporates many of the familiar (though sometimes controverted) assumptions of the quantity-theoretic literature. Among other things, there is assumed to be a welldefined distinction between "monetary" and "non-monetary" assets, with all assets either counting as part of the balances that supply liquidity services or not; there is assumed to be a stable functional

\footnotetext{
11 Again, if the limit does not exist, the left-hand side of (1.12) should be understood to refer to the lim sup.
} 
relationship between the level of real money balances and the utility flow from such services (resulting in a stable "money demand function" (1.8a)); all households are assumed to be identical and infinite-lived, so that variations in the distribution of money holdings are not contemplated; and there are no restrictions upon a household's ability to exchange financial assets and goods for one another at any time. Nonetheless, I wish to show that this system of equilibrium conditions does not lead so inevitably to "monetarist" conclusions as is often supposed.

In particular, I would like to suggest, developing an idea discussed both in Sims (1994) and in my earlier paper (Woodford, 1994), ${ }^{12}$ that it is often more useful to think of (1.10), rather than (1.8a), as the equilibrium condition that determines the equilibrium price level at date $t$. Equation (1.8a) must also be satisfied, but it may more usefully be viewed as determining the money supply, in the case of an endogenous-money policy regime. Even in the case of an exogenous money supply, (1.8a) may more usefully be viewed as the condition that determines the equilibrium interest-rate differential, rather than as the relation that directly determines the equilibrium price level.

Determination of the price level by (1.10) confirms the suggestion of Sargent (1982) that the fiscal policy regime matters for the equilibrium value of money, because the value of money, like other government debt, depends upon "private agents' expectations about the revenue streams backing" it. The analysis to be presented here shows that this is a coherent view of the determinants of the value of money, even in the case of inconvertible fiat money. ${ }^{13}$

Apart from the fact that $(1.10)$ is shown to be a necessary condition for perfect foresight equilibrium, one can give a simple interpretation to the mechanism by which the price level adjusts to satisfy (1.10), assuming full price flexibility. ${ }^{14}$ Briefly, an increase in the nominal value of outstanding government liabilities, or in the size of the (appropriately modified) real government budget deficits expected at some future dates, is inconsistent with equilibrium at the existing price level. For either change causes households to believe that their budget set has expanded (assuming no change in the path of the price level), and so they demand additional consumption immediately (as well as planning higher consumption in the future). The consequence would be excess demand for goods (both now and in the future). This forces up prices (assuming $W_{t}>0$ ), to the extent that the

\footnotetext{
12 Leeper (1991) also illustrates how the price level may be determined by the government budget, in the case of what he calls an "active" fiscal policy combined with "passive" monetary policy. He does not, however, emphasize, or strictly speaking even justify the imposition of, an equilibrium condition like (1.10). Instead, he restricts attention to the bounded solutions to a system of linearized equilibrium conditions, including a linearized version of a condition similar to (1.11); the restriction to bounded solutions then implies (1.12) and hence a condition like (1.10).

${ }^{13}$ Sargent's discussion is not explicit as to whether the applicability of a "backing" theory depends upon an expectation that the country in question will eventually return to a gold standard, as was arguably the case for the central European countries in the aftermath of World War I with which he is concerned.

${ }^{14}$ Condition $(1.10)$ continues to be a necessary condition for equilibrium even in the case of a model where goods prices in terms of money are predetermined; however, in that case, short-run adjustment occurs through variations in equilibrium output, rather than in the price level. One then has a theory of the effects of fiscal variables upon aggregate demand and hence upon short-run variations in economic activity. This extension will be taken up in a subsequent paper.
} 
capital loss on the value of net outside assets restores households' estimates of their wealth to ones that just allow them to afford to purchase the quantity of goods that the economy can supply (and that are not consumed by the government). Price level determination thus depends upon a wealth effect of price level changes, as in the analysis of Patinkin (1956), but in contrast to Patinkin's analysis of the "real balance effect", I find that the effect in question depends upon the value of net outside assets, rather than upon the value of the monetary base. 15

The directness of the connection between a discrepancy between the values of the left and right hand sides of (1.10) and economic forces that should cause the price level $p_{t}$ to adjust makes it plausible to view (1.10) as being the crucial relation that determines the price level; at least at this rather superficial level, the fiscal theory would seem at least as plausible as the quantity theory. But the ultimate usefulness of such a view depends upon observing how the entire system of simultaneous equilibrium conditions works to determine the equilibrium paths of the price level and other variables at once, in the context of a complete specification of the policy regime. I will argue that the fiscal theory provides a useful way of viewing the implications of the above model, in a wide range of circumstances. First of all, it directs attention to the role played by variables such as net government liabilities and expectations regarding future government budgets in price level determination, and I will argue that changes in such variables do affect the equilibrium price level, quite independently of any changes in the path of the money supply that may be associated with them. And second, it de-emphasizes the role of the money supply as a determinant of the equilibrium price level, and in so doing makes it intuitive that the price level may be perfectly determinate even under a regime with a completely elastic money supply.

I take up the first point first. It is illustrated in the next section, through consideration of a series of alternative policies in the context of the model set out above. It is shown that in the case of a certain simple policy regimes, the effects of policy changes are indeed more easily understood when one thinks of the price level as being determined by (1.10) rather than by (1.8a). I first consider this issue in the context of policies that involve exogenously fixing the time path of the money supply. Subsequent sections then consider regimes in which the money supply is endogenous.

\section{Price Level Determination with an Exogenous Money Supply}

In this section I consider the role of the government budget in price level determination in the case of a policy regime that fixes the time path of the money supply. It is perhaps useful to begin by recalling how quantity-theoretic analyses argue that the path of the price level can be determined

\footnotetext{
${ }^{15}$ The question of whether capital gains and losses on the value of nominal government debt should have a similar wealth effect is of course taken up by Patinkin; for further discussion of the issue, see section 3.
} 
in such a case without any reference to the time path of government deficits or of the outstanding government debt.

In rational-expectations versions of the model of Cagan (1956), it is assumed that desired real money balances are a decreasing function of the expected rate of inflation, so that (1.8a) becomes

$$
M_{t} / p_{t}=f\left(p_{t+1} / p_{t}\right)
$$

where $f$ is a monotonically decreasing function. Here it is admitted that various real factors affect the form of the function $f$, but it is assumed that the additional arguments can be suppressed (in the case that time variation in those real factors is regarded as negligible), on the ground that real and nominal variables dichotomize. It is then argued that in the case of an exogenously specified evolution $\left\{M_{t}\right\}$ for the money supply, the money supply sequence and condition (2.1) alone determine the equilibrium price level sequence

$\left\{p_{t}\right\}$. Thus the specification of the time path of the government budget deficit, among other things, is irrelevant for determination of the price level.

A familiar problem with such an account is that given the absence of an initial condition, the difference equation (2.1) may well admit a continuum of solutions for the price level sequence. (This corresponds, in turn, to a much larger set of possible solutions in the stochastic extension of the model.) It is typically supposed, however, that an additional formal criterion, involving only the sequences $\left\{M_{t}\right\}$ and $\left\{p_{t}\right\}$, can be used to select the "correct" solution; often this amounts to excluding solutions in which real money balances asymptotically become either unboundedly large or unboundedly small. With this additional proviso it is argued that one can solve for $p_{t}$ as a function of the expected sequence $\left\{M_{s}\right\}$ for

$s \geq t$ (Sargent, 1987a, pp. 196-197; McCallum, 1989, pp. 148-155).

\section{A. An Irrelevance Proposition for Changes in the Money Supply}

The model set out in the previous section results, in many circumstances, in a different conclusion, but not because one cannot derive an equilibrium condition of the form (2.1). Let us specialize, in this section, to the case of preferences of the familiar form

$$
U(c, m)=u(c)+v(m)
$$

where $u$ and $v$ are each increasing, concave, differentiable functions defined for all non-negative values of their arguments. The significance of assuming (2.2) is that in this special case, $\lambda(c, \Delta)=$ $u^{\prime}(c)$ is independent of $\Delta$, so that (1.8b) gives an expression for the real interest rate that depends only upon the time path of the real resources available for consumption. This makes the real interest rate on bonds $r_{t}{ }_{t}$ independent of money holdings and of inflation (in the case of an exogenously given path for real government purchases

$\left.\left\{g_{t}\right\}\right)$, as is typically assumed in the quantity-theoretic literature. (This conclusion is not true of the Sidrauski-Brock model in the case of more general preferences.) 
One can then use ( $1.8 \mathrm{~b})$ to obtain an expression for $R^{b}{ }_{t}$ in terms of the real resources available for consumption in periods $t$ and $t+1$, and expected inflation between these two periods. Substituting this into $(1.8 \mathrm{a})$ yields

$$
\frac{M_{t}}{p_{t}}=L\left(y_{t}-g_{t}, \quad 1-\beta R_{t}^{m} \frac{u^{\prime}\left(y_{t+1}-g_{t+1}\right)}{u^{\prime}\left(y_{t}-g_{t}\right)} \frac{p_{t}}{p_{t+1}}\right)
$$

If one assumes constant exogenous values for the variables $y_{t} g_{t}$, and $R^{m_{t}}$ then (2.3) becomes an equilibrium condition of the form (2.1) to solve for $\left\{p_{t}\right\}$ given the sequence $\left\{M_{t}\right\}$. (Note that (2.2) implies that $L$ is monotonically decreasing in its second argument.)

Nonetheless, the outstanding government debt and the expected path of government budget deficits may well affect the equilibrium price level, even when they have no effect upon the path of the money supply. Furthermore, it is even arguable that the expected path of the money supply does not matter for price level determination, except through its consequences for the government's budget. In order to state an irrelevance proposition of this kind, one needs to define what it would mean to neutralize the fiscal effects of a change in the money supply. For this purpose it is useful to consider a rule for net tax collections of the form

$$
T_{t}=p_{t} x_{t}-\Delta_{t} M_{t}
$$

where $\left\{x_{t}\right\}$ is an exogenous sequence. One can think of this as a rule in which there is a proportional income tax, with the tax rate varying exogenously over time, but with the further stipulation that the government's interest savings from the fact that some of its liabilities are monetary are rebated lump-sum to the private sector. ${ }^{16}$ (Because the endowment process $\left\{y_{t}\right\}$ is exogenous, an income tax is equivalent to a lump-sum tax, with the real net tax to be collected being exogenously specified.)

The point of the final term in (2.4) is to make it possible to consider the effects of a change in the money supply $M_{t}$, without these implying a change in the expected real value of the government's total liabilities at the beginning of the following period. Note that (2.4) implies that the law of motion (1.11) for net government liabilities becomes

$$
W_{t+1}=R_{t}^{b}\left[W_{t}+p_{t}\left(g_{t}-x_{t}\right)\right]
$$

Thus a change in the money supply $M_{t}$ in the absence of any change in $g_{t} x_{t}$ or $p_{t}$, will not imply any change in $W_{t+I} / R^{b} t$, or (given that the real rate of return on bonds is not affected by changes in the level of real money balances) in the expected value of $W_{t+I} / p_{t+I} \cdot{ }^{17}$

\footnotetext{
${ }^{16}$ The exogeneity of $\left\{x_{t}\right\}$ thus implies that changes in the path of the money supply $\left\{M_{t}\right\}$ have no effect upon the proportional income tax rate. They do affect total real net tax collections $T_{t} / p_{t}$, but only through the effect of changes in the money supply upon the government's total interest obligations, and hence upon the size of the lump-sum "rebate".

${ }^{17}$ It might be thought that the obvious way to neutralize the consequences of the path of the money supply for the government budget would be to rebate lump-sum the government's seignorage revenues $M_{t}-R_{t-1}^{m} M_{t-1}$. This amounts to ensuring that a change in $M_{t}$ does not imply any change in $B_{t}$ (or in $B_{t} / p_{t}$ or the expected value of $R^{b}{ }_{t} B_{t}\left(p_{t+1}\right)$. One can also in this case obtain a monetary irrelevance proposition similar to the one stated below. The
} 
Finally, the degree to which it is possible to independently specify the paths of monetary and fiscal variables, consistent with the existence of an equilibrium, is greatest if one further assumes that

$$
v^{\prime}(m)<u^{\prime}(\bar{y})
$$

for all $m>0$, where $\bar{y}$ is an upper bound for the endowment $y_{t}$ and that

$$
\text { sup } m \geq 0 m v^{\prime}(m)<\infty .
$$

Assumption (2.6) implies that desired real balances become arbitrarily small in the case of a sufficiently large interest rate differential between money and bonds. It ensures that we can solve (1.8a) for the equilibrium interest rate differential for any positive level of real money balances (assuming $0 \leq g_{t}<y_{t} \leq \bar{y}$ ). Assumption (2.7) implies a bound upon the real value of the tax rebates implied by the second term on the right hand side of (2.4), regardless of the path followed by the real money supply. For equilibrium conditions (1.7a) -- (1.7b) imply that

$$
\sum_{i=0}^{\infty} \frac{\Delta_{t} m_{t}}{\Pi_{s=0}^{t-1}\left(1+r_{s}^{b}\right)}=\frac{1}{u^{\prime}\left(c_{0}\right)} \sum_{t=0}^{\infty} \beta^{t} m_{t} v^{\prime}\left(m_{t}\right) .
$$

It then follows from (2.7) that the contribution of these terms to the lifetime budget of the representative household will be finite, regardless of the behavior over time of the real money supply. One can now state the following proposition regarding irrelevance of the money supply for price level determination.

Proposition. Let preferences satisfy (2.2), (2.6) and (2.7), and let the policy regime be specified by exogenous sequences $\left\{g_{t}, x_{t}, M_{t}, R^{m}\right\}$ satisfying $0 \leq g_{t}<y_{t} \leq \bar{y}$; $M_{t} R^{m}{ }_{t}>0$; and

$$
\begin{array}{r}
0<\sum_{s=1}^{\infty} \beta^{s-t}\left[x_{s}-g_{s}\right] u^{\prime}\left(y_{s}-g_{s}\right)<\infty \\
-\infty<\sum_{s=t}^{\infty} \beta^{s-t}\left[y_{s}-x_{s}\right] u^{\prime}\left(y_{s}-g_{s}\right)<\infty
\end{array}
$$

at each date $t \geq 0$. Net tax collections are then given each period by (2.4). Finally, assume that initial net liabilities of the government satisfy $W_{0}>0$. Associated with any such regime is a unique perfect foresight equilibrium; in particular, there are unique equilibrium sequences $\left\{p_{t}, R_{t}^{b}, B_{t} W_{t}\right\}$. Furthermore, at any date $t$, given the predetermined quantity $W_{t}$, the equilibrium price level $p_{t}$ depends solely upon expectations regarding the fiscal variables $\left\{g_{s}, x_{s}\right\}$ for $s \geq t$, and not upon current or expected future values of the monetary variables $\left\{M_{s}, R^{m}\right\}$.

Note that the restrictions placed by (2.8a) -- (2.8b) and the other inequalities upon feasible sequences $\left\{g_{t}, x_{t}\right\}$ is independent of the path chosen for the money supply $\left\{M_{t}\right\}$; and similarly, the money supply can follow any positive sequence, regardless of the choice of the fiscal variables. Thus

disadvantage is that in that case, definition of the class of exogenous sequences consistent with existence of equilibrium is more complex. However, announcement at date $t$ of a new path for $\left\{M_{s}\right\}$ for $s \geq t$, from within the class of such paths consistent with existence of an equilibrium, again has no effect upon the price level at date $t$. 
the existence result implies that monetary and fiscal policy can indeed be independently chosen, if these policies are specified in terms of the variables used in the statement of the proposition. ${ }^{18}$ The uniqueness result implies that a policy regime of this kind does determine the equilibrium price level. But it is not the fact that the path of the money supply is exogenously specified that is responsible for this. Indeed, in a sense that the proposition makes precise, both the current money supply and its expected future path are irrelevant to the determination of the equilibrium price level.

The reason is simple. Given preferences satisfying (2.2) and a fiscal policy rule of the form (2.4), (1.10) becomes

$$
\frac{W_{t}}{p_{t}}=\sum_{s=t}^{\infty} \beta^{s-t} \frac{u^{\prime}\left(y_{s}-g_{s}\right)}{u^{\prime}\left(y_{t}-g_{s}\right)}\left[x_{s}-g_{s}\right]
$$

Condition (2.8a) implies that the right hand side of (2.9) is finite and positive at all times. Given that $W_{t}$ is a predetermined state variable, the equilibrium price level $p_{t}$ is therefore uniquely determined by (2.9), without any reference to the values of the sequences $\left\{M_{s}, R^{m_{s}}\right\}$ at any dates $s \geq$ $t$. Thus under a regime of the kind described, the price level is determined by (1.10) rather than by (1.8a); and it follows directly from this that a change in the current or expected future government budget deficit will affect the equilibrium price level, while a change in the current or expected future money supply, in the absence of any change in the fiscal variables, will not. ${ }^{19}$

Condition (1.8a) is, of course, still a necessary condition for equilibrium. But this does not mean that the value of $M_{t}$ plays any role in the determination of $p_{t}$. Instead, (1.8a) determines the equilibrium interest rate differential. Given an exogenous interest rate $R^{m_{\Delta}}(1.8 \mathrm{a})$ then implies that the equilibrium interest rate on bonds must equal

$$
R_{t}^{b}=R_{t}^{m} \frac{u^{\prime}\left(y_{t}-g_{t}\right)}{u^{\prime}\left(y_{t}-g_{t}\right)-v^{\prime}\left(M_{t} / p_{t}\right)}
$$

Condition (2.6) implies that this liquidity preference relation determines an interest rate $R^{b}>R^{m}$ for arbitary $M_{t}, p_{t}>0$.

One can then construct the complete perfect foresight equilibrium sequences as follows. Given $W_{0}>0,(2.9)$ determines a unique $p_{0}>0$. Given $p_{0}>0,(2.10)$ determines a unique $R^{b}>$ 0 . Given $p_{0}$ and $W_{0},(2.5)$ uniquely determines $W_{1}$. And (2.9) implies that $W_{1}>0$, so that one may undertake a similar construction at date $t=1$, and similarly at all later dates. By construction, these

\footnotetext{
${ }^{18}$ There is thus, with such a division of roles, no conflict between the monetary and fiscal authorities of the kind discussed in Sargent (1985).

${ }^{19}$ The role of condition (2.2) is to make the marginal utility of income $u^{\prime}\left(y_{s}-g_{s}\right)$ independent of a household's real money balances, and hence to make the real rate of interest given by $(1.7 \mathrm{~b})$ independent of the path of real balances, and hence independent of the path of inflation. Without this "superneutrality" result, the right hand side of $(1.10)$ cannot be evaluated without solving for the equilibrium path of real balances. Furthermore, an exact irrelevance result will not generally hold. However, in the non-separable case, the effects of a change in the money supply on the price level $p_{t}$ come about solely through the effects of the change in the real interest rate upon the present value of expected future government surpluses -- i.e., from the fact that in this case, policy rule (2.4) does not fully neutralize the fiscal consequences of such a change.
} 
sequences satisfy (1.8a) and (1.10) at all dates. Comparison of (2.5) with (2.9) allows one to verify that the constructed sequences $\left\{p_{t}, R^{b} t\right.$ imply a real interest rate sequence $\left(r_{t}^{b} t\right.$ that satisfies $(1.8 \mathrm{~b})$ at all dates as well. It remains only to verify that for these sequences, the infinite sum on the right hand side of (1.6) is well-defined and finite. Substituting (2.4), one observes that this involves evaluation of the present value of a sequence of terms of the form $y_{t}-x_{t}+\Delta_{t} m_{t}$. The present value of the $y_{t}$ - $x_{t}$ terms is well-defined and finite by $(2.8 \mathrm{~b}) ;(2.7)$ implies that the present value of the $\Delta_{t} m_{t}$ terms is well-defined and finite as well. Thus all requirements for a perfect foresight equilibrium are satisfied.

Note that the irrelevance result states only that the announcement of a new path for the money supply at some date $t$ has no effect upon the price level at that date. It does not imply that there is no eventual effect upon the price level. However, any such effects come about only as a result of the eventual effects of monetary policy upon the size of total government liabilities, which then affects the price level through (2.9). And even in this case, it is arguable that such effects upon the price level as occur are due to fiscal effects of the policy change, rather than upon the mere fact that households are forced to hold a different quantity of money; for the price level grows in proportion to the growth of total government liabilities $W_{t}$, and not in proportion to growth of the monetary component of those liabilities.

Indeed, if one is able to insulate the nominal rate of return on bonds from changes in the real money supply, a stronger irrelevance proposition is obtained. Consider a policy regime defined by exogenous sequences $\left\{g_{t}, x_{t}, M_{t}, R^{b}\right\}$, where now $R^{m_{t}}$ (rather than $R^{b} t$ adjusts endogenously to equate money supply and demand. Then given $W_{t}$, the entire equilibrium sequence $\left\{p_{s}\right\}$ for $s \geq t$ is independent of the expected path of $\left\{M_{s}\right\}$ for $s \geq t$. For in this case, (2.9) determines $p_{t}$ given $W_{t}$, and (2.5) then determines $W_{t+1}$, all without any reference to the money supply. This construction can be repeated indefinitely. Thus there is again a unique equilibrium price level sequence, and it is independent of either the current or expected future money supply. ${ }^{20}$ This sort of policy regime is clearly of less practical interest, given present monetary institutions; but the thought experiment helps to clarify the fact that even in the previous case, monetary policy affects the price level only because of its effect upon the interest that the government must pay on its debt, and hence upon the growth of government liabilities.

Nor are the eventual effects upon the price level of a change in the money supply in the previous case of the kind that are implied by conventional quantity-theoretic reasoning. For a contraction of the money supply, by raising the nominal interest rate on bonds, causes total government liabilities to grow faster, and this results in a higher eventual price level rather than a

\footnotetext{
${ }^{20} \mathrm{~A}$ similar result is obtained, even for the kind of policy regime described in the proposition, in the case of a liquidity preference function that is infinitely elastic, so that the equilibrium interest rate differential does not vary with the real money supply. This case is of relevance for the discussion of an economy with private supply of money in section 5.
} 
lower one. This result is in the spirit of the "unpleasant monetarist arithmetic" of Sargent and Wallace (1981), although the argument is slightly different. Sargent and Wallace argue that a monetary contraction, in the absence of fiscal reform, can be inflationary because it results in faster growth of the government debt, that they assume must eventually be monetized. Thus the inflationary result of the policy is linked, in their analysis, to the fact that in the long run, the policy change results in a higher rather than a lower money supply. Yet that need not be so in the case described in the proposition above. A permanent reduction in the money supply, with no change in the expected paths of the fiscal variables, implies a permanently higher path for the price level; this is because the increased nominal value of total government liabilities is inflationary even if it is never monetized. The connection between higher government liabilities and a higher price level is a direct one, not dependent upon an implication of an eventual increase in the money supply.

\section{B. Comparing the Effects of Increases in Money and in Debt}

The above irrelevance proposition does not deny, of course, that a "helicopter drop" of additional money into an economy with no outstanding government debt, that is then left in circulation permanently, results in a permanent, proportional increase in the price level. Consider the case in which the endowment and each of the policy variables is expected to remain constant over time, with the constant values satisfying $M>0, R^{m}=1$ and

$$
v^{\prime}\left(\frac{x-g}{1-\beta}\right)=(1-\beta) u^{\prime}(y-g),
$$

and in which the initial nominal value of net government liabilities is $W_{0}=M$. In this case, the unique perfect foresight equilibrium involves a constant price level $p$ forever (and a zero government debt forever). ${ }^{21}$ Now suppose that at date 0 there is an unexpected "helicopter drop" of additional currency in the amount of $(\lambda-1) M$ units, for some $\lambda>1$. The money supply is again expected to remain constant thereafter, and no changes are made in the announced paths for government purchases, the tax rate (i.e., for tax collections prior to the rebate of interest savings), or the interest paid on money. In terms of the above notation, the new policy regime involves a path for the money supply of $M_{t}=\lambda M$ for all $t \geq 0$; real tax revenues of $x_{0}=x-(\lambda-1) M / p_{0}$, while $x_{t}=x$ for all $t \geq 1$; and unchanged paths for $\left\{g, R^{m}\right\}_{t}$. Again there is a unique perfect foresight equilibrium, and constructing it as above one finds that again the price level is constant for all dates $t$ $\geq 0$, but at the higher level of $\lambda p$.

However, the proposition makes clear that in such an experiment, it is the reduction of taxes net of transfers at date $t=0$, rather than the increase in the money supply, that is responsible for the increase in the equilibrium price level. Indeed, the price level would increase at date $t=0$ by exactly the same amount if a fiscal transfer of nominal value $(\lambda-1) M$ were made at that date, with no change

\footnotetext{
${ }^{21}$ It will be observed that in this equilibrium, real net tax collections each period are given by $\tau=g$.
} 
in the expected value of $x_{t}$ subsequently, even if the path of the money supply were still expected to be $M_{t}=M$ for all $t \geq 0 .{ }^{22}$ (One might think of this as a "helicopter drop" of government debt.) In this latter case, the nominal value of government liabilities would not only remain permanently higher, but would grow without bound over time; for, relative to the equilibrium in which the money supply is increased at the time of the transfer, the real money supply in this equilibrium would be uniformly lower, resulting in a higher nominal interest rate and hence a faster rate of growth of net government liabilities. As a result, the price level would grow asymptotically without bound (in proportion to the growth of net government liabilities). ${ }^{23}$

Such an experiment indicates that an increase in the government budget deficit can be inflationary, even when it implies no increase in the money supply at any later date. The point made by this example is thus somewhat different than that of Sargent (1985) and Aiyagari and Gertler (1985), who argue that increases in government debt are inflationary if the interest and/or principal on the debt is paid through a subsequent increase in money creation, rather than out of increased taxes. In the above example, the "helicopter drop" of government debt does not imply any change in the expected future path of the money supply, nor any change in future seignorage revenues (which continue to be zero).

Instead, it implies an increase in the present value of future net tax collections, equal to the value of the initial transfer. This comes about through the feedback rule (2.4) for net tax collections; real net tax collections $\tau_{t}$ increase insofar as $\Delta_{t} M / p_{t}$ decreases. This latter term is equal to $m_{t}$ $\nu\left(m_{t}\right) / u^{\prime}(y-g)$ in the equilibrium described above, so that net taxes increase uniformly (given the uniformly higher price level) if $m v^{\prime}(m)$ is an increasing function of $m$; in any event, net taxes eventually increase, as this term asymptotically approaches zero due to (2.6). The present value of the entire sequence of terms is given by

$$
\sum_{i=0}^{\infty} \beta^{t} \Delta_{t} m_{t}=\sum_{t=0}^{\infty} \beta^{t}\left[m_{t}-\beta m_{t+1}\right]=m_{0},
$$

so that the present value of real net tax collections increases by the amount by which $M / p_{0}$ declines, which is to say by

$$
\frac{M}{p}-\frac{M}{\lambda p}=\frac{(1-\lambda) M}{\lambda p}
$$

\footnotetext{
${ }^{22}$ This point is reminiscent of a criticism often raised by James Tobin against the strong "monetarist" proposition that only the path of the money supply matters for price level determination (e.g., Tobin, 1974, p. 87). But Tobin argues that a "rain" of Treasury bills should also increase prices, not because government liabilities as such should have this effect,but because Treasury bills are somewhat money-like (as indicated by the fact that they exhibit a liquidity premium, albeit not so large a one as for currency). The present analysis, by contrast, accepts the quantity-theoretic assumption of a sharp distinction between money and bonds, and assumes that only money provides liquidity services; it is argued nonetheless that an increase in government debt can increase the price level.

${ }^{23}$ In the case that $\nu^{\prime}(0)<u^{\prime}(y-g)$, one can show that the rate of growth of government debt and the rate of inflation asymptotically approach a finite value, given by $\beta u^{\prime}(y-g) /\left[u^{\prime}(y-g)-\nu(0)\right]>1$. Even when this is not true, one can show that the real value of government debt approaches an asymptote.
} 
the real value of the transfer at date $t=0$. Thus the mere fact that a transfer implies a future increase in direct taxes rather than in future seignorage revenues does not in itself imply that the transfer does not affect the price level; indeed, in the thought experiment just described, net taxes increase only because of a rise in the price level. 24

Not only would the initial price-level effect of the "helicopter drop" of additional money be the same in the case of a "helicopter drop" of additional government debt, but it would fail to exist if the money supply were permanently increased by the same amount, but without any increase in net transfers to the private sector; the effect in such a case would be just the opposite of that in the case of a permanent reduction in the level of the money supply, discussed above. ${ }^{25}$ Thus such effects as a change in the money supply has on the price level are quite dependent upon the fiscal aspects of the policy change; injection of new money through an open-market exchange of money for bonds has very different effects than injection of new money through a transfer to the private sector.

The theory developed here implies, furthermore, that increases in the money supply through open market operations should have different consequences for the price level than increases through "helicopter drops". This issue has, of course, long been debated among monetary economists, at least since the writings of John Stuart Mill (Kohn, 1988). Friedman (1974, pp. 146-148) argues that any differences in the effects of an increase in the money supply that depend upon the way in which the money supply comes to increase will be merely "first-round effects", that he suggests should last for only a few weeks. ${ }^{26}$ Presumably Friedman has in mind effects that are neutralized once households are able to adjust their portfolios to "undo" the effect of the government's action, but that may not be immediately neutralized due to frictions that prevent such portfolio adjustments for

\footnotetext{
${ }^{24}$ This example should not be taken to suggest that a "helicopter drop" of government debt is possible, in the absence of any change in the path of the money supply, only if future tax collections increase. In fact, a pure bond-financed deficit is possible, in which the initial transfer results neither in higher real tax collections nor in a different path for the money supply (or for real seignorage revenues). Consider a modification of the above example, in which the initial steady state is one in which $\tau>\mathrm{g}$, and the steady-state level of real government debt is positive. (Initial conditions consistent with the steady state then require that $W_{0} / M$ take a certain value greater than 1 .) Then consider a "helicopter drop" of government debt, and suppose that real tax collections each period remain fixed at the value $\tau$ (except for the initial transfer), in addition to maintaining the constant money supply $M$, the constant level of government purchases $g$, and the constant zero rate of interest on money. Such a policy also results in the existence of a unique perfect foresight equilibrium, and again the "helicopter drop" of government debt results in inflation. In this case, the real value of the government debt continues to equal the present value of expected future net primary government budget surpluses $\tau-\xi$, but this comes about solely as a result of the capital loss on the initially outstanding government debt when the new government debt is issued and the price level increases. Such an example illustrates that a pure bond-financed deficit is consistent with perfect foresight equilibrium, but that it is inflationary. The example does not contradict McCallum's (1984) result that "a permanent deficit cannot be financed solely with bonds if the deficit is defined exclusive of interest payments" (p. 132), for it does not involve a permanent deficit; the initial deficit is instead followed by a permanent primary budget surplus.

25 Again there would be no immediate effect on the price level, but eventually the price level would fall, as the higher real money supply led to lower interest rates on government debt, and this in turn to a lower rate of growth of net government liabilities.

${ }^{26}$ See also Friedman and Schwartz (1982, pp. 29-31).
} 
a short time, as in the models of Lucas (1990) and Fuerst (1992). ${ }^{27}$ But the failure here of the "monetarist" proposition that fiscal policy is irrelevant to price level determination is not dependent upon the existence of such frictions. My point is rather that a "monetary" policy change that is not fiscally neutral cannot be "undone", at unchanged prices and interest rates, by a simple portfolio adjustment on the part of households. Thus not only should the fiscal aspects of a policy change affect the price level, but there is no reason to expect these effects to be merely transient.

\section{Comparison with Traditional Analyses}

Where is the flaw in the traditional quantity-theoretic analysis, sketched at the beginning of this section? Condition (2.3) is indeed a necessary condition for perfect foresight equilibrium. But it does not suffice to determine the price level. Given (2.6), it is possible to solve (2.3) for $p_{t+1}>0$, regardless of the value of $p_{t}>0$. Hence one may arbitrarily select a value for $p_{0}>0$, and find a sequence $\left\{p_{t}\right\}$ consistent with it that satisfies (2.3) for all $t \geq 0$; there is thus a continuum of solutions to (2.3). Quantity-theoretic analyses assume that one can select the "correct" solution on the basis of some criterion that does not involve reference to the behavior of variables other than the money supply and the price level. But in the case of the kind of policy regimes referred to in the proposition above, this is clearly incorrect. For each such regime, there is a unique perfect foresight equilibrium path for the price level. But which of the solutions to (2.3) is actually an equilibrium depends upon the specification of the fiscal variables.

For example, in the case of the "helicopter drop" of government debt just discussed, the set of paths for the price level that satisfy (2.3) is not affected. But the particular element of the set that happens to be consistent with the full set of requirements for perfect foresight equilibrium changes, from the constant-price-level solution to one that involves a higher price level at all times, and a price level that eventually becomes unboundedly large. The existence of the latter kind of solutions to (2.3) has often been recognized in the quantity-theoretic literature, but they have been characterized as "self-fulfilling inflations" or "bubbles" (McCallum, 1989, pp. 158-160; Blanchard and Fischer, 1989 , ch. 5). The suggestion is that such paths could occur only as a result of arbitrary expectations of such an outcome, despite an absence of objective conditions that would suggest it. But this is clearly not true of the equilibrium just described; for the price level grows only insofar as the nominal value of net outside assets does, and the explosive growth of the latter is a mechanical consequence of the government budget deficits.

Under certain side conditions, of course, it is known that (2.3) has a unique solution for the path of the price level. Obstfeld and Rogoff (1983) give a careful discussion of this issue, in the context of a policy regime in which there is zero interest on money, the money supply is constant

${ }^{27}$ Cagan (1972) discusses in detail the transient character of such "portfolio effects", on both theoretical and empirical grounds. 
over time, and the supply of government debt is always zero. ${ }^{28}$ Under certain conditions, they obtain a unique equilibrium price level path. However, this requires an assumption on preferences that contradicts (2.6); they characterize the restriction needed as "very severe", and argue that it is unlikely to be a property of an indirect utility function derived from an explicit model of the transactions role of money (p. 683). In the absence of that restriction, they find that a continuum of "speculative hyperinflationary paths" exist for any given constant money supply.

They argue more generally that solutions to (2.3) in which real money balances asymptotically become unboundedly large do not correspond to equilibria. This is because such paths violate a transversality condition, that the present value of money holdings by the representative household asymptotically become zero, that they show in their model is necessary for optimization over the infinite horizon. In fact, in the case of a policy regime in which the supply of government bonds is zero at all times, (1.12) reduces to

$$
\lim _{T \rightarrow \infty} \frac{R_{T}^{m} M_{T}}{\Pi_{s=0}^{T} R_{s}^{b}}=0,
$$

and in the case of zero interest on money this is equivalent to the condition used by Obstfeld and Rogoff. However, in the case of policy regimes of the kind described in the above proposition, (2.11) is not a necessary condition for equilibrium. Equilibria of the kind constructed above will, for some specifications of the monetary and fiscal policy sequences, imply explosive growth of real money balances, to such an extent that (2.11) is violated. These solutions still satisfy (1.12), as this follows from (1.10), and so they involve the supply of government debt eventually becoming negative -. i.e., the government must become a net lender to the private sector. This comes about because the stipulation that the composition of government liabilities is determined by the government's insistence upon a certain exogenous path for money holdings $\left\{M_{A}\right\}$ can mean, in the case that the price level falls sufficiently relative to the desired money supply, that the government must be willing to lend to households to allow them to finance money holdings of that magnitude. Because their monetary assets are offset by debt, households are not over-accumulating wealth along such paths. ${ }^{29}$

Some may object that equilibria in which the price level grows at a rate that is either persistently greater than, or persistently less than, the rate of growth of conventional monetary

\footnotetext{
${ }^{28}$ In fact, their model ignores government debt, and includes another asset, "nondepreciating capital". But neither closing the bond market, nor treating capital as an asset that can be traded, rather than as a stream of endowment income, changes the set of equilibria.

${ }^{29}$ The fact that the present value of real balances remains bounded above zero does not in such a case imply that a household could increase lifetime utility by increasing consumption by one dollar at some date, without reducing consumption at any later date, and reducing its money holdings permanently by one dollar at that date. (This is instead true in the case considered by Obstfeld and Rogoff; see their p. 681, following Brock, 1975.) For the borrowing limit (1.3) allows the household to borrow to the extent that it does only because its debts are offset by its money holdings, and this limit would be violated by a change in the household's plan of the kind proposed. Some solutions to (2.3) involving explosive real money balances can be excluded as equilibria in the case of other types of borrowing limit.
} 
aggregates are not actually observed, and feel that this casts doubt upon the correctness of the above analysis. However, the mere failure to observe such equilibria does not in any way show that the government budget does not determine the equilibrium price level in the way illustrated by the above examples. It could simply indicate, instead, that actual policy regimes do not involve an exogenous specification of the path of the money supply, of the kind assumed in the above examples. In other words, it might simply be that central banks never allow the money supply to become too much out of line with the general level of prices, while the path of the price level is determined by essentially fiscal factors. (Examples of endogenous-money regimes in which the price level is determined by the expected future path of the government budget, but in which the money supply necessarily grows at the same rate as the price level, are provided in sections $\mathbf{4}$ and 5.) The point of discussing less realistic policy regimes, like the "helicopter drop" of government debt combined with a fixed money supply, is simply that the consideration of such cases brings into sharper focus my basic point -- that it is the growth of total government liabilities (relative to expected future government budget surpluses) that determines the growth of the price level, rather than the growth of the money supply. Only when one contrives an example in which the two factors diverge is it possible to see which is truly determinative.

\section{Ricardian and Non-Ricardian Policy Regimes}

I have argued in the previous section that the quantity equation, and condition (2.3) developed from it, will often not suffice to determine the equilibrium price level, even though it is a necessary condition for perfect foresight equilibrium, and that often it is expectations regarding fiscal policy that supply the missing element. Indeed, it is often useful to regard expectations regarding fiscal policy as the direct determinant of the price level, through condition (1.10). It should be noted, however, that in the case of a certain kind of specification of fiscal policy, neither the government budget deficit nor the size of the government debt plays any role in price level determination, for (1.10) is trivially satisfied, regardless of the price level; and in this "Ricardian" case, traditional quantity-theoretic analysis is correct. But I will argue that there is no reason in general to assume a policy regime of this special kind. In the more general case, condition (1.10) does matter for price level determination, and as a result quantity-theoretic conclusions may be quite misleading.

As an example, consider a policy regime in which the sequences $\left\{g_{t}, M_{D} R^{m} t\right.$ are exogenously specified, while tax collections are determined by a feedback rule

$$
T_{t}=p_{t} g_{t}-\left[M_{t}-R_{t-1}^{m} M_{t-1}\right]+\gamma R_{t-1}^{b} B_{t-1}
$$

for some $0<\gamma \leq 1$. That is, tax collections each period equal the cost of the exogenously determined government purchases, minus the exogenously determined level of seignorage collected during the 
period, plus a certain fraction of the amount owed by the government on its outstanding debt at the beginning of the period. Under such a rule, the government financing constraint (1.5) implies that $B_{t}=(1-\gamma) R_{t-1}^{b} B_{t-1}$, which in turn guarantees that

$$
\lim _{T \rightarrow \infty} \frac{B_{T}}{\Pi_{s=0}^{T-1} R_{s}^{b}}=0
$$

regardless of the paths of the price level or of nominal interest rates. But given (3.2), (2.11) becomes necessary and sufficient for (1.12), and hence for (1.10) to hold.

Then sequences $\left\{p_{t}, R^{b} t\right.$ describe a perfect foresight equilibrium if and only if they satisfy (1.8a) and (1.8b) for all $t$, and furthermore satisfy (2.11) and

$$
\sum_{t=0}^{\infty} \beta^{t} \lambda\left(y_{t}-g_{t}, \Delta_{t}\right)\left[y_{t}-g_{t}+\Delta_{t} m_{t}\right]<\infty
$$

given the exogenous sequences $\left\{M_{t}, R^{m}, g_{t} y_{t}\right\}$. (The last inequality is necessary and sufficient for the right hand side of (1.6) to be finite, given (1.8b) and (1.9), which last follows from (2.11).) Note that none of these conditions involves the initial level of outside assets, or the subsequent evolution of tax collections or the government debt. Nor does the derivation of these conditions involve any aspect of the rule (3.1), except that it guarantees (3.2). For example, a change in the level of tax collections for any finite number of periods, with (3.1) to apply thereafter, results in exactly the same conclusion. Thus both the initial level of the government debt, and its subsequent evolution thereafter as a consequence of the level of tax collections, are found to be completely irrelevant for the determination of the set of perfect foresight equilibrium paths for the price level, and for interest rates as well.

This irrelevance result, in the spirit of the results of McCallum (1984) and Sargent (1987b, Prop. 5.3), is plainly an extension of the familiar "Ricardian equivalence" proposition regarding the irrelevance of the government debt for real quantities, such as the real interest rate (e.g., Barro, 1974). For this reason, I propose to call a policy regime "Ricardian" if, as in the example just described, the exogenous sequences and feedback rules that specify the policy regime imply that (3.2) necessarily holds, regardless of the behavior of other endogenous variables - in particular, regardless of the evolution of the price level. ${ }^{30}$ Note that given (1.5), (3.2) is equivalent to

$$
B_{t-1}=\sum_{s=1}^{\infty} \frac{\left(T_{s}-p_{s} g_{s}\right)+\left(M_{s}-R_{s-1}^{m} M_{s-1}\right)}{\Pi_{j=l-1}^{s-1} R_{j}^{b}}
$$

\footnotetext{
${ }^{30}$ This definition is related to Leeper's (1991) concept of "passive" fiscal policy. Leeper, however, defines "passive" fiscal policy only in the context of a particular parametric family of policy rules. His definition corresponds, furthermore, to a requirement that the real value of the government debt, $B_{t} / p_{t}$, remain bounded forever, rather than that its present value approach zero, as in (3.2); and this is required to be true only in the case of arbitrary price level paths involving bounded fluctuations in the rate of inflation, $\log \left(p_{t+1} / p_{t}\right)$, rather than more generally. His requirements are thus both weaker and stronger than mine (in different respects).
} 
Thus one may equivalently characterize "Ricardian" regimes as ones in which (3.3) necessarily holds, independently of what the evolution of $\left\{p_{t}\right\}$ may be. ${ }^{31}$

In the case of any such regime, fiscal policy plays no role at all in price level determination (except insofar as the path of real government purchases affects real interest rates), while the path of the money supply clearly does. Hence traditional quantity-theoretic reasoning is, in such a case, completely valid. ${ }^{32}$ Note that the case most often assumed in theoretical work in the quantitytheoretic tradition, of a policy regime in which the supply of government bonds is exogenously fixed at zero, is necessarily of this kind. The assumption in this literature that it suffices to analyze the case of a regime without government debt is due, I suspect, to a tacit assumption that the policy regime should in any event be Ricardian, so that the equilibrium conditions that determine the price level are equivalent to those of a regime without government debt.

But there is no reason to restrict attention to the case of Ricardian regimes, and it should be evident that such regimes represent a highly special case. For there is no reason why a wellformulated policy rule must force (3.2) to hold, regardless of the path of the price level. I do not mean to deny that (3.2) -- or equivalently, (3.3)-- should typically hold in equilibrium. For in general, (2.11) will hold in equilibrium, ${ }^{33}$ and given (2.11), equilibrium condition (1.10) holds if and only if (3.2) does, so that (3.2) must hold. ${ }^{34}$ But this will in general imply a restriction upon the possible perfect foresight paths of the price level, rather than being a condition that would necessarily hold in the case of any expected path of the price level. (Recall, for example, the consequences of a "helicopter drop" of government debt in the previous section. Condition (3.3) holds, as a result of the way tax collections increase due to the rise in the price level -- but it holds only because the price level rises, in equilibrium, by exactly the right amount.) It is exactly for this reason that, in the case of a non-Ricardian policy regime, (1.10) can restrict the set of possible equilibrium price level paths, though it does not in the case of a Ricardian policy.

\footnotetext{
${ }^{31} \mathrm{My}$ use of the term is thus different from that of Aiyagari and Gertler (1985), despite some similar emphases in their analysis. They call a regime "Ricardian" only if the value of government debt $B_{t-1}$ is necessarily equal to the present value of future tax collections $\left\{T_{s}\right\}$. Thus they would classify as "non-Ricardian" a regime under which (3.3) necessarily holds, but only due to variation in subsequent seignorage revenues in response to changes in the value of government debt. ${ }^{32}$ This does not mean that a policy that fixes the path of the money supply exogenously necessarily determines a unique path for the price level. Indeed, under the assumptions of the proposition in the previous section, but substituting (3.1) for (2.4), one can show that there exists a continuum of perfect foresight equilibria, one for each possible initial price level $p_{0}>0$. However, the set of equilibrium paths for the price level is unaffected by a "helicopter drop" of additional government debt. A similar result is obtained if a rule like (3.1) for fiscal policy is combined with an interest rate peg of the kind considered in the next section.

${ }^{33}$ I have noted in the previous section that existence of an optimum plan for the representative household implies that the present value of all future terms of the form $\Delta_{s} M_{t}$ must be finite. This implies that the present value of $\Delta T_{T} M_{T}$ must converge to zero as $T$ is made large. As long as the non-negative quantity $\left(R^{m} T\right)^{-1}-\left(R^{b} T\right)^{-1}$ remains bounded away from zero for all $T$, this implies (2.2).

${ }^{34}$ One can argue more directly for (3.3) in the case that households are constrained to hold non-negative quantities of bonds. Then (1.12) continues to be necessary for equilibrium, but due to the non-negativity of holdings of both money and bonds, (1.12) would then imply both (2.11) and (3.3).
} 
It will be observed that the policy regimes discussed in the previous section are nonRicardian, and indeed this is essential to the effects of fiscal policy upon the price level illustrated there. The non-Ricardian character of the policy rules in question implies no internal inconsistency, and in particular does not preclude the existence of a perfect foresight equilibrium, in which the expectation that government policy will adhere to the rules stated is fulfilled.

A n even simpler example of a non-Ricardian policy would be one similar to that advocated by Friedman (1959). Let the money supply $\left\{M_{t}\right\}$ follow an exogenous path, as in the previous section, and let there be zero interest paid on money. ${ }^{35}$ Furthermore, let neither real government purchases nor tax rates vary in response to the state of the economy; thus (assuming an exogenous sequence $\left\{y_{t}\right\}$ for real output) the sequences $\left\{g_{t}\right\}$ and $\left\{\tau_{t}\right\}$ are both exogenously specified (and deterministic) ${ }^{36}$ This implies that the government's budget is not to be adjusted so as to ensure that (3.2) holds, and indeed, many authors have criticized Friedman's proposal on the ground that it would imply an explosive path for the government debt (e.g., Blinder and Solow, 1976; Turnovsky, 1977; Christ, 1979; Scarth, 1980; McCallum, 1981b, 1984). But this does not mean that independent variations in the various exogenous series (and in the initial net liabilities of the government), over some range, do not continue to be consistent with the existence of equilibrium. What it does mean is that in such a regime, the equilibrium price level will depend upon fiscal policy; and that as a result, merely fixing an appropriate growth rate of the money supply does not suffice to ensure a desired rate of inflation. 37

It is perhaps worthwhile to discuss why the government is not constrained to follow a Ricardian policy. Equation (3.3) states that the present value of future primary government surpluses must equal the value of outstanding government debt, if now "primary surpluses" are defined somewhat differently than before, to equal the excess of tax revenues plus seignorage revenues over government spending. This is often described as a present-value budget constraint for the government, which description makes it seem natural to suppose that the government must plan to satisfy it. Thus it might seem that any coherent policy regime must be Ricardian.

\footnotetext{
${ }^{35}$ The specification of zero interest on money does not follow Friedman (1959), though it has often been assumed in the critical literature relating to Friedman's proposals.

36For purposes of this discussion, I shall interpret $R^{m_{t}}$ and $R^{b}$ to refer to the after-tax interest yield of money and bonds. 37The "pure bond-financed deficit" described in footnote 24 illustrates this. McCallum (1984) fails to obtain such a result because he does not consider the experiment described in the previous footnote. Instead, he considers only the case of a permanent deficit, and shows that no equilibrium is possible, inflationary or otherwise. He restricts attention to this case because he takes it for granted that unless a policy is inconsistent with (3.3), Ricardian equivalence must hold. But inconsistency with (3.3) means that there can exist no equilibrium. Non-Ricardian results are instead obtained in the case that (3.3) is satisfied for some pricelevel and interest rate paths, but is not necessarily satisfied Ricardian equivalence holds only if (3.3) is satisfied for all price level and interest rate paths (or, to be more precise, all that are consistent with the other equilibrium conditions), so that it becomes a redundant equilibrium condition.
} 
But there is no institution that imposes such a budget constraint on the government in an economy that is expected to continue into an indefinite future. ${ }^{38}$ This is made clear by the analysis of equilibria with government debt in the overlapping generations model of Diamond (1965). Diamond shows in a simple example how it is possible for government debt to be issued that is expected to be "rolled over" forever. The conditions required for this to be possible in equilibrium are somewhat special and probably not empirically realistic; but the example demonstrates that it is not a requirement for the logical coherence of the policy regime that it exclude such an outcome.

In the model of the previous section, such an outcome can be excluded in equilibrium. This is essentially an application of Walras's Law. It is well-known that when Walras's Law holds (i.e., when individual economic units' budgets can be aggregated to obtain a well-defined present value for aggregate expenditure), the joint requirements that each unit's budget constraint be satisfied with equality and that each market clear contain a redundant equation. (Often this is taken to be one of the market-clearing conditions, so that it is found that clearing of $N-1$ markets implies clearing of the $N$ th market as well, but it might equally well be one of the budget constraints that is implied by the others.) Then clearing of all markets implies that if the representative household's present-value budget constraint holds with equality, a similar present-value relation (1.10) must hold with equality for the government.

In an overlapping generations model, this last conclusion need not follow; each generation alive at a given point in time may plan future expenditure in excess of income with a present value equal to its wealth, and yet the same not be true of the stream of future aggregate private expenditure in excess of income and current aggregate private wealth. Thus Walras's Law can fail for such an economy. This depends, as explained by Shell (1971), upon the existence of an infinite sequence of distinct households and present values of aggregate private expenditure and income that are infinite. In the representative-household model, by contrast, this cannot occur, and so an appropriately formulated present-value budget constraint must hold for the government in any equilibrium. But this is a property of equilibrium, that follows from market-clearing and optimization by households, and not an institutional constraint upon the kind of plans that the government can make, as a function of the expected path of prices.

The invalidity of an assumption that governments are constrained to satisfy a present-value budget constraint in the same way as private economic units is recognized by Patinkin (1965), who also regards this difference as crucial for price level determination, though he does not appear to see that this removes the analytical basis for the Ricardian postulate. Regarding the "real-balance effect", which in Patinkin's system is the reason for the invalidity of a dichotomy between real and nominal variables, and hence for determinacy of the equilibrium price level, he writes (p. 288):

\footnotetext{
38 It seems to me that the situation is different in the case of private borrowers, insofar as operation of a "Ponzi scheme" can be prosecuted as fraud.
} 
We note finally that, in a certain sense, the real-balance effect is ... a distribution effect. For our fiat paper money is the debt of the government; and if the government were to react to changes in the real value of this debt as do households and firms to theirs, there could be no net real-balance effect in the economy as a whole. Any, say, decrease in the price level would generate a positive real-balance effect for households and firms and an exactly offsetting negative one for the government. Thus the preceding analysis has been based on the tacit -- though realistic -- assumption that the government, alone of all economic units, is unconcerned with the real value of its outstanding (noninterest-bearing) debt, and plans its demand for commodities accordingly.

This "tacit -- though realistic -- assumption" is exactly the one that I wish to consider here, except that I see no justification for the "noninterest-bearing" qualification. Patinkin appears to take the view that "the interest burden on [government] bonds must be financed by future taxes" (p. 289), despite what he has said about the government being unconcerned with the value of its outstanding debt, but it is hard to see why. ${ }^{39}$ If one pursues the "tacit assumption" to its logical conclusion, one indeed obtains a theory of price level determination through a "real-balance effect" of price level changes upon the aggregate demand for goods; but, as observed earlier, it is the change in the real value of net government liabilities, rather than real money balances, that matters for this. ${ }^{40}$

We thus see that in the case of non-Ricardian policies, one may usefully think of the price level as being determined by fiscal variables rather than by the path of the money supply. Consequently, it should no longer come as any surprise that the price level may be perfectly determinate in a regime that leaves the money supply to be determined endogenously. I now return to this issue, beginning with the case of an endogenous money supply due to an elastic supply of money by the central bank, in order to peg the interest rate on government debt.

\footnotetext{
${ }^{39}$ See Sweeney (1988) for a thorough critical discussion of issues raised by Patinkin's analysis. He takes for granted that policy must be Ricardian, but accordingly reaches the conclusion that there should be no distribution effect of the kind that Patinkin argues for.

40 Patinkin does consider the possibility that the "real-balance effect" depends upon the real value of government debt as well as the money supply (pp. 289-294), but he argues that this is so only to the extent that households fail to correctly take account of the consequences of a price level change for their future tax liabilities; in other words, this possibility depends upon a denial of rational expectations. Other authors have similarly obtained an effect of government debt upon the price level (e.g., Brunner and Meltzer, 1976, pp. 84-85) by assuming, for whatever reason, that private spending depends upon a wealth aggregate that includes the market value of government debt. The novelty of the present analysis consists solely in a demonstration that such effects do not depend upon myopia, bequest constraints, or liquidity constraints.
} 


\section{Consequences of an Interest Rate Peg}

It will be observed that conditions (1.8a) and (1.8b) have the homogeneity properties stressed in the quantity-theoretic literature: the only ways in which the price level enters are as a ratio to the money supply (in (1.8a)) and in the form of the expected inflation rate (in (1.8b)). This is the reason for the common conclusion that a policy regime that leaves the money supply, as well as the price level, endogenous will not be able to determine the level of either, leaving the level of all nominal quantities to be determined by self-fulfilling expectations.

However, such an argument neglects the role of equilibrium condition (1.10). In general, this equilibrium condition will not exhibit the homogeneity property just mentioned, due to the presence of the ratio of $W_{t}$ to the price level on the left-hand side. And indeed, there may well be a unique path for the price level that satisfies this equation.

Consider for example, a pure interest-rate peg in which government policy exogenously specifies the sequences $\left\{R^{m_{t}}, R^{b}{ }_{t} g_{t} \tau_{t}\right\}$, letting the total value of government liabilities be determined by (1.5) and leaving the composition of those liabilities to be determined by households. Again, substitution of (1.8a) and (1.8b) into (1.10) yields

$$
\frac{W_{t}}{p_{t}}=\frac{1}{\lambda\left(y_{t}-g_{t}, \Delta_{t}\right)} \sum_{s=t}^{\infty} \beta^{s-t} \lambda\left(y_{s}-g_{s}, \Delta_{s}\right)\left[\left(\tau_{s}-g_{s}\right)+\Delta_{s} L\left(y_{s}-g_{s}, \Delta_{s}\right)\right]
$$

This condition relates the equilibrium price level at any date $t$ to the nominal value $W_{t}$ of net government liabilities at that time, and upon the anticipated value of the policy variables from that time onward. Assuming a policy specification in which $R^{m_{s}}<R^{b_{s}}, g_{s}<y_{s}$ each period, such that the infinite sum on the right hand side of (4.1) is positive, the equation can be solved for a unique price level $p_{\mathrm{t}}>0$, given net government liabilities $W_{\mathrm{t}}>0$.

Substituting (1.8a) into (1.11) yields

as a law of motion for net government liabilities (or net outside assets of the private sector). Given the policy variables, the system (4.1) -. (4.2) describes the evolution of the series $\left\{p_{b} W_{A}\right\}$, given an initial level of government liabilities. Each period, given the stock of government liabilities at the beginning of the period, (4.1) determines the price level, given which (4.2) determines the stock of government liabilities at the beginning of the following period, and so on forever. In this manner one may solve for the complete paths of all endogenous variables. If in addition the exogenous sequences are such that

$$
-\infty<\sum_{i=0}^{\infty} \beta^{t} \lambda\left(y_{t}-g_{t}, \Delta_{t}\right)\left[y_{t}-\tau_{t}\right]<\infty
$$

then the solution is one in which the right hand side of (1.6) is well-defined and finite, and so corresponds to a perfect foresight equilibrum. 
Thus one obtains a unique perfect foresight equilibrium path for all prices and quantities. Note that price level determinacy is possible in the case of a pure interest rate peg, in which is there is not expected to be any feedback from the path of the price level or other nominal variables to the interest rate. Thus the point is a somewhat different one than that made by McCallum (1981a), who shows that determinacy is possible in the case of a rule under which the nominal interest rate is predetermined, if the interest rate is set in a way that involves the right kind of feedback from a lagged endogenous nominal variable, such as the price level.41 McCallum uses a rationalexpectations IS-LM framework similar to that of Sargent and Wallace (1975), and so does not obtain an equilibrium condition analogous to (1.10). 42 Determinacy in the case of a pure interest rate peg, by contrast, is obtained in representative-household general-equilibrium models closely related to this one by Begg and Haque (1984), Auernheimer and Contreras (1990), Sims (1994), and Woodford (1994), in each case through an equilibirum condition similar to (1.10). 43

Nor is it necessary that fiscal policy be specified in exactly the way just proposed, in order for there to be a determinate price level under a pure interest rate peg. For example, one might suppose instead that the government exogenously chooses the sequences $\left\{G_{t}, T_{t}\right\}$,

where $G_{t}=p_{t} g_{t}$ denotes nominal government purchases. In this case $(1.10)$ becomes $\frac{1}{p_{t}}\left[W_{t}+\sum_{s=t}^{\infty} \frac{\left.G_{s}-T_{s}\right\rceil}{\Pi_{j=t}^{s-1} R_{j}^{b}}\right\rfloor=\frac{1}{\lambda\left(y_{t}-g_{t}, \Delta_{t}\right)} \sum_{s=t}^{\infty} \beta^{s-t} \lambda\left(y_{s}-g_{s}, \Delta_{s}\right) \Delta_{s} L\left(y_{s}-g_{s}, \Delta_{s}\right)$

One again sees that, in general, if the policy regime is consistent with the existence of any perfect foresight equilibrium (i.e., if the quantity in square brackets on the left hand side is finite and positive, the infinite sum on the right is finite, and the solution implies a finite value for the right hand side of (1.6)), the price level is uniquely determined. ${ }^{44}$

Similarly, it is not necessary that all government liabilities be denominated in units of money, as assumed thus far. Suppose, instead, that all government bonds are indexed. Then (1.2) can be replaced by

$$
W_{t}=M_{t-1} R^{m_{t-1}}+p o\left(1+b_{t-1}\right) b_{t-1}
$$

where $b_{t-1}$ is the real value of government debt outstanding at the end of period $t-1$, and both $M_{t}$. ${ }_{l} R^{m} t_{t l}$ and $\left(1+t_{t-1}^{b}\right) b_{t-1}$ are predetermined variables in period $t$. In this case, (1.10) becomes $\frac{R_{t-1}^{m} M_{t-1}}{p_{t}}=\frac{1}{\lambda\left(y_{t}-g_{t}, \Delta_{t}\right)} \sum_{s=t}^{\infty} \beta^{s-t} \lambda\left(y_{s}-g_{s}, \Delta_{s}\right)\left[\left(\tau_{s}-g_{s}\right)+\Delta_{s} L\left(y_{s}-g_{s}, \Delta_{s}\right)\right]-\left(1+r_{t-1}^{b}\right) b_{t-1}$

${ }^{41}$ See Boyd and Dotsey (1994) for further development of this point.

${ }^{42}$ One might interpret the model of Sargent and Wallace (1975) as implicitly assuming a Ricardian fiscal policy rule, in the sense of section 3 .

${ }^{43}$ For extensions of the analysis to the case of an open economy, see Auernheimer and Contreras (1993) and Bergin (1995).

${ }^{44}$ One difference between this case and the previous one is that now the price level is indeterminate in the case of an interest rate peg in which $R^{b}=R^{m}$ in all periods, whereas $(1.10)$ still determines a unique price level in that limiting case, as long as desired real balances remain finite even in the limit of a zero interest rate differential. 
Again one observes that if the policy is consistent with the existence of any equilibrium, the equilibrium price level is uniquely determined. ${ }^{45}$

One could continue to multiply examples, but the point should be clear: equilibrium condition (1.10) is in general not redundant, and can easily determine a unique price level consistent with perfect foresight equilibrium. These examples indicate the usefulness, at least in the case of policy regimes involving an interest rate peg, of regarding (1.10), rather than (1.8a), as the equilibrium condition of fundamental importance for price level determination. Even in the case of a Ricardian fiscal policy rule, this seems a reasonable view, though in that case (1.10) fails to place any restriction upon the path of the price level.

For it makes as much sense in such a case to say that the price level is indeterminate because the fiscal policy regime makes the expected nominal value of future government surpluses vary with the price level, so that (1.10) fails to place any restriction upon the price level, as it does to say that the indeterminacy results from a monetary policy under which the money supply varies with the price level, so that (1.8a) fails to place any restriction upon the price level.

I have shown that the equilibrium price level is uniquely determined in the case of an interest-rate peg, in the case of an appropriately chosen fiscal policy rule. This conclusion indicates that quantity-theoretic reasoning can be quite misleading, at least in the case of certain kinds of policy regimes. Nor is the special case considered here one of interest solely as a debating point. Many authors have argued that there are good (microeconomic) reasons for a central bank to wish to fix the level of nominal interest rates exogenously, rather than allowing it to respond to innovations in the price level or the quantity of money (e.g., Sargent and Wallace, 1982; Mankiw, 1987; Barro, 1989; Woodford, 1990; Goodfriend, 1991). It is thus of considerable practical interest to know whether a straightforward pursuit of such an aim would result in macroeconomic instability. In answering this question, the fiscal theory of price level determination sketched in the previous section would seem to be more useful than a quantity-theoretic approach.

\section{Consequences of Private Issuance of Money Substitutes}

I now take up the question of the threat to price level determinacy posed by allowing private intermediaries to engage in unrestricted creation of substitutes for government-issued money. That is, I will suppose that private intermediaries could create financial assets with all of the advantages

\footnotetext{
${ }^{45} \mathrm{Nor}$ is it necessary to assume that only one-period bonds are traded, as is assumed here for notational convenience. With longer-maturity government debt, $W_{t}$ ceases to be a predetermined variable, even when there is no indexation; it will depend upon the term structure of interest rates at date $t$. But in the case of a pure interest rate peg, $W_{t}$ is still uniquely determined by the policy specification (given the amount and structure of initially outstanding government debt), and independent of the price level; so that $(1.10)$ continues to uniquely determine the price level, assuming that $W_{t}>0$.
} 
possessed by the monetary base in facilitating transactions, at least if regulations did not prohibit this activity. I then ask whether it is necessary, in order to ensure that self-fulfilling expectations cannot cause unexpected variation in the price level, that financial innovation of this kind be controlled or prohibited.

The issue can be addressed within the framework of section 1 if one continues to assume that utility is increased by real balances in the same way as before, but allows other assets than the monetary base to count as "real balances" for this purpose. Specifically, I will assume in this section that each household seeks to maximize

$$
\sum_{t=0}^{\infty} \beta^{t} U\left(c_{t}, \frac{M_{t}+D_{t}}{p_{t}}\right)
$$

where $D_{t}$ indicates the nominal value at the end of period $t$ of the household's deposits with an intermediary, which deposits are the money substitutes just referred to. ${ }^{46}$ Constraint (1.1) remains as before, except that a term $D_{t}$ must be added to the left-hand side; and the term $B_{t}$ is replaced by $B^{h}{ }_{t}$, to indicate household bond holdings (that need no longer equal the government bond supply). Equation (1.2) remains the same, except that a term $D_{t} R^{d}{ }_{t}$ must be added to the right-hand side, where $R^{d}$ is the gross nominal return on deposits held from dates $t$ to $t+1$; and again $B_{t}$ is replaced by $B^{h}{ }_{t}$. It is also assumed that the household is subject to an additional non-negativity constraint each period, $D_{t} \geq 0$. The borrowing limit (1.3) is unchanged.

The intermediation technology allows an intermediary that obtains deposits with nominal value $D_{t}$ to purchase government bonds in period $t$ with a fraction 1- $\rho$ of that value; but a fraction $0<\rho<1$ of the value of the deposits must be spent on purchases of goods that are consumed inthe activity of the intermediary. Thus I assume costs of intermediation that are proportional to the quantity of savings intermediated (as, for example, in Bryant and Wallace, 1981). Competition between intermediaries, with free entry, requires that in equilibrium

$$
R_{i}^{d}=(1-\rho) R_{i}^{b}
$$

The supply of money-like deposits will be perfectly elastic at this rate of interest. Market-clearing in the bond market then requires

$$
B_{t}^{h}+(1-\rho) D_{t}=B_{t}
$$

where $B_{t}$ denotes the supply of government bonds, as before. And market-clearing in the goods market now requires

\footnotetext{
46It is important to note that these deposits do not refer to the checkable deposits that are subject to reserve requirements under current U.S. institutional arrangements; as noted earlier, the demand for such deposits is counted as part of the demand for the monetary base $M$. Note also that $D$ more precisely refers not to the nominal value of deposits with the unregulated intermediaries, but rather to the amount by which a household is able to reduce its (direct or indirect) holdings of the monetary base, without any reduction in transactions services, thanks to its holdings of such deposits. The logic here is the same as in our elimination of inside money from explicit representation in household budget constraints.
} 


$$
c_{t}+g_{t}+\rho \frac{D_{t}}{p_{t}}=y_{t}
$$

As before, equilibrium also requires that household holdings of money equal the money supply.

It is obvious that a household will hold money only if $R^{m} t \geq R_{b}$ and will hold deposits only if $R^{d_{t}} \geq R^{m}$. Its total demand for money-like assets is then given by

$$
\frac{M_{t}+D_{t}}{p_{t}}=L\left(c_{t}, \Delta_{t}\right)
$$

where $L(c, \Delta)$ is the same function as before, but the interest-rate differential now defined as

$$
\Delta_{t}=\frac{R_{t}^{b}-\max \left\{R_{t}^{m}, R_{t}^{d}\right\}}{R_{t}^{b}}
$$

Alternatively, it is useful to define functions $c^{*}(e, \Delta)$ and $m^{*}(e, \Delta)$ as the solutions for $c$ and $m$, respectively, to the problem of maximizing $u(c, m)$ subject to the constraint

$$
c+\Delta m \leq e .
$$

Then the total demand for money-like assets can equally well be written as

$$
\frac{M_{t}+D_{t}}{p_{t}}=m *\left(e_{t}, \Delta_{t}\right)
$$

where

$$
e_{t}=c_{t}+\Delta_{t}\left(\frac{M_{t}+D_{t}}{p_{t}}\right)
$$

is the household's "total expenditure" (counting the interest cost of maintaining money-like balances to facilitate consumption spending).

Using (5.1), one sees that a household will hold money only if $\Delta_{t} \leq \rho$, while it will hold deposits only if $\Delta_{t} \geq \rho$. Thus an equilibrium in which both assets coexist necessarily involves an interest-rate differential (between bonds and either of the money-like assets) of $\Delta_{t}=\rho$. For this reason, the model is essentially one in which the total supply of money-like assets $M_{t}+D_{t}$ is infinitely elastic at the nominal interest rate spread of $\rho$, regardless of how inelastic the supply of government money $M_{t}$ may be. In this respect, such a regime is similar to a pure interest rate peg of the kind considered in the previous section, though it is not the behavior of the central bank that results in the elastic money supply. Alternatively, one may note that the demand for real (government-supplied) money balances is in this case infinitely elastic, at a point at which both money and deposits are held, in the sense that the household will vary its demand for real money balances from zero to $m^{*}\left(e_{t}, \Delta_{t}\right)$ in response to an infinitesimal change in $R^{m}$. I wish to consider whether this elastic supply of total money-like assets, or this indeterminacy of desired governmentsupplied money balances, implies indeterminacy of the equilibrium price level, as quantity-theoretic reasoning would suggest. 
As a simple example, let us consider a policy regime in which the sequences $\left\{M_{\downarrow} R^{m_{\hbar}} \tau_{b}\right\}$ are exogenously specified, with $M_{t}, R^{m}{ }_{t}>0$ at all dates, while government purchases are determined by a feedback rule of the form

$$
g_{t}=z_{t}+\Delta_{t} m_{t}
$$

where $\left\{z_{t}\right\}$ is an exogenous non-negative sequence, and $m_{t}$ refers as before to the real value of government monetary liabilities. As with the exogenous-money regimes considered in section 2, $\left\{R_{t}^{b}\right\}$ is left to be determined in the bond market, and the evolution of $\left\{B_{t}\right\}$ is determined by the government financing constraint (1.5), that is unchanged.

Endogenous variation in government purchases according to (5.4) again, as with (2.4), allows consideration of variations in the path of the money supply that have no effect upon the (modified) government budget surplus $\tau_{t}-g_{t}+\Delta_{t} m_{t}$, so that a change in $M_{t}$ in the absence of any change in the fiscal variables $\tau_{t}$ or $z_{t}$, implies no change in $W_{t+1} / R^{b}$. The reason for now achieving this through endogenous variation in $g_{t}$ rather than variation in $\tau_{t}$ as before, is that (5.4) also eliminates the effect of changes in the real (government) money supply upon the net supply of goods available for consumption by the private sector, due to (5.3). With the intermediation technology described above, that net supply is $y_{t}-g_{t}-\rho\left(D_{t} p_{t}\right)$, and this is affected by the supply of government money insofar as the use of government money saves society the resources that would be consumed in intermediation in the case of private money substitutes. But in any equilibrium in which government money is held, household optimization implies that

$$
\left(\Delta_{t}-\rho\right)\left(D_{t} / p_{t}\right)=0
$$

so the net supply of goods available for private consumption can alternatively be expressed as $y_{t}-g_{t}$ $\Delta_{t}\left(D_{t} p_{t}\right)$. The economy's resource constraint then requires that in equilibrium, $e_{t}=y_{t}-z_{t}$, using (5.4). This in turn implies equilibrium private consumption of $c^{*}\left(y_{t}-z_{t} \Delta_{t}\right)$, and a total demand for real balances of money-like assets of $m^{*}\left(y_{t}-z_{t}, \Delta_{t}\right)$.

One can again show that $(1.10)$ is a necessary condition for perfect foresight equilibrium, despite the occurrence of privately issued deposits in both the new expression for $e_{t}$ and in equilibrium condition (5.3), that it is used to substitute for private consumption demand. (Here (5.5) is again used to cancel the terms.) In the case of feedback rule (5.4), and restricting attention to the case in which both money and deposits are held, (1.10) takes the form

$$
\frac{W_{t}}{p_{t}}=\frac{1}{\lambda *\left(y_{t}-z_{t}, \rho\right)} \sum_{s=t}^{\infty} \beta^{s-t} \lambda *\left(y_{s}-z_{s}, \rho\right)\left[\tau_{s}-z_{s}\right]
$$

where

$$
\lambda *(e, \Delta)=u_{c}\left(c^{*}(e, \Delta), m^{*}(e, \Delta)\right) \text {. }
$$

Given the exogenous sequences $\left\{\begin{array}{lll}y_{b} & z_{b} & \tau_{t}\end{array}\right.$, and net government liabilities 
$W_{t}>0$ at the beginning of the period, it is evident that (5.6) uniquely determines the price level $p_{t}{ }^{47}$ One can also derive a law of motion for net government liabilities analogous to (4.1), namely

$$
W_{t+1}=\frac{R_{t}^{m}}{1-\rho}\left[W_{t}+p_{t}\left(z_{t}-\tau_{t}\right)\right]
$$

The system (5.6) - (5.7) then uniquely determines the complete evolution of the sequences $\left\{W_{t}, p_{t}\right\}$, given an initial condition $W_{0}>0$. If the exogenous sequences are such that

$$
\sum_{s=t}^{\infty} \beta^{s-t} \lambda^{*}\left(y_{s}-z_{s}, \rho\right)\left[\tau_{s}-z_{s}\right]<\infty
$$

for each $t \geq 0$, then equations (5.6) -- (5.7) imply that $W_{t} p_{t}>0$ at all dates. If in addition they are such that

$$
-\infty<\sum_{t=0}^{\infty} \beta^{t} \lambda *\left(y_{t}-z_{t}, \rho\right)\left[y_{t}-\tau_{t}\right]<\infty,
$$

then the right hand side of (1.6) is well-defined and finite. Finally, if the sequence $\left\{p_{t}\right\}$ implied by (5.6) - (5.7) is such that

$$
M_{t}<p_{t} m^{*}\left(y_{t}-z_{t} \rho\right)
$$

at each date $t \geq 1$, then the sequences so constructed do imply that households hold positive quantities of both money and deposits at each date, and so they correspond to a perfect foresight equilibrium.

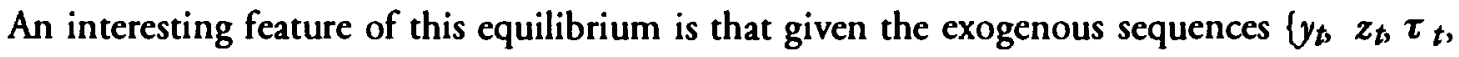
$R^{m} A$ and the initial condition $W_{0}$, the complete equilibrium path of the price level $\left\{p_{t}\right\}$ is independent of the announced path for the money supply $\left\{M_{A}\right\}$, as long as that path satisfies (5.8) at each date. (Note that one can compute the right hand side of $(5.8)$ using only the sequences $\left\{y_{t}, z_{t}\right.$ $\tau_{t}, R_{t} m_{\text {and }}$ the initial condition $W_{0}$, and so define the range of variation in the path of the money supply that is consistent with the existence of such an equilibrium.) The equilibrium path of the price level is in this case determined solely by the fiscal variables (and by the rate of interest paid on government money).

Thus the existence of unrestricted private supply of money substitutes need pose no threat to the determinacy of the equilibrium price level. ${ }^{48}$ This is hardly a surprising result from the point of view of the fiscal theory of the price level; there is no obvious reason why the existence of substitutes for government-supplied money should interfere with the existence of determinate expectations regarding the present value of future government surpluses, or with the existence of determinate equilibrium path for the evolution of outstanding government liabilities. Indeed, it should be clear that the result just obtained as to the determinacy of the equilibrium price level is in no way

${ }^{47}$ Here uniqueness is demonstrated only within the class of equilibria such that both money and deposits are held; but this construction suffices at least to establish that equilibrium is determinate in the sense of local uniqueness.

${ }^{48} \mathrm{~A}$ similar result is obtained in the limiting case $\rho=0$ (costless intermediation), as long as there is satiation in moneylike assets at some finite level of holdings of such assets, so that $m^{*}(c, 0)$ is well-defined and finite. 
dependent upon a policy regime of the precise form assumed above; this case is simply convenient in allowing one to derive a closed-form expression (5.6) for the equilibrium price level from (1.10).

Consequently, there is no obvious reason for regulatory policy toward financial intermediaries to seek either to prevent the creation of money substitutes, or to ensure that all money-like liabilities are equally subject to reserve requirements - at least if such efforts to preserve a well-defined demand for the monetary base are intended to allow control of the price level. This does not mean that the unrestricted supply of private money substitutes would have no consequences for monetary policy or for the path of the price level.

It would remove the ability of the central bank to determine the interest-rate differential between monetary and non-monetary assets at any level that it might choose. This might be thought to remove an important instrument of stabilization policy. But it is odd to see quantity theorists, who often argue for the desirability of restrictions upon the scope of discretionary monetary policy, call for regulation in order to preserve the central bank's power to intervene in financial markets in this way.

It would also remove the ability of the central bank to determine even the long-run rate of inflation, if it is taken to be institutionally necessary that $R^{m} t=1$ at all times. For as long as both money and the money substitute are held, elastic supply of the money substitute implies that $\boldsymbol{\Delta}_{\boldsymbol{t}}=\boldsymbol{\rho}$ at all times, so that if there is zero nominal interest paid on money, $R^{b} t=(1-\rho)^{-1}$. Equation (1.8b) then implies that

$$
\frac{p_{t+1}}{p_{t}}=\frac{\beta}{1-\rho} \frac{\lambda\left(y_{t+1}-z_{t+1}, \rho\right)}{\lambda\left(y_{t}-z_{t}, \rho\right)}
$$

Thus, unless government purchases are used to change the trend growth of the net supply of goods available for private consumption, the trend rate of inflation is independent of government policy. ${ }^{49}$ This confirms the claim by proponents of laissez-faire monetary arrangements that elimination of the government monopoly of money creation would serve to prevent inflation (e.g., Hayek, 1978)..$^{50} \mathrm{~A}$ mistaken belief that allowing competitive supply of money substitutes would result in indeterminacy of the price level thus has serious consequences, in that it provides the intellectual basis for resistance to policies that may be useful, not only on grounds of microeconomic efficiency, but from the point of view of controlling inflation as well.

\footnotetext{
${ }^{49}$ Actually, if $\rho>0$, it is possible to choose a policy that results in existence of an equilibrium in which only governmentsupplied money is held. In this case, equilibrium requires only that $1 \leq R^{b}{ }_{t} \leq(1-\rho)^{-1}$; but this still implies that the rate given in (5.8) is an upper bound upon the equilibrium inflation rate. If $\rho$ is small, the range of possible equilbrium inflation rates is correspondingly small..

${ }^{50}$ See Cowen and Kroszner (1994) for a review of related literature.
} 


\section{Conclusion}

I have shown that determinacy of the price level is possible even in regimes in which the money supply is endogenous -- indeed, in which it is perfectly elastic, at a given short-term interest rate -- either because the central bank pegs the interest rate, or through the competitive supply of private substitutes for government-issued money. Thus avoidance of policies of these kinds is not necessary for the sake of allowing control of the general level of prices, especially if, as many have argued, such policies are desirable from the point of view of microeconomic efficiency.

I have also argued that analysis in terms of a simple quantity-theoretic framework has led to confusion on this score, and have suggested an alternative approach to the analysis of price level determination, in which the government's budget plays a central role.

None of my criticism of quantity-theoretic analyses is meant, however, to deny the importance of the service that quantity theorists such as Milton Friedman have rendered to contemporary discussion of issues of macroeconomic policy, especially in their insistence upon attention to the consequences of macroeconomic policies for inflation, and upon the importance of a government commitment to a policy rule as a crucial element in creating a stable environment for private enterprise. Criticisms of analytical problems raised by quantity-theoretic reasoning have sometimes been supposed to cast doubt upon these more fundamental commitments of the quantity theorists as well, but nothing that I have said here should be taken in that light.

I have assumed a reader who is concerned with the design of policy to ensure price level stability. And the theory of price level determination sketched here only makes it more evident that stability of expectations regarding future government policy is essential for stability of the price level and (once one allows for short-run price stickiness) of the degree of utilization of productive capacity. I have sought simply to question whether the form of policy rule that would best serve these fundamental aims is one based upon control of a monetary aggregate. 


\section{REFERENCES}

Aiyagari, S. Rao, and Mark Gertler, "The Backing of Government Bonds and Monetarism," Journal of Monetary Economics 16: 19-44 (1985).

Auernheimer, Leonardo, and Benjamin Contreras, "Control of the Interest Rate with a Government Budget Constraint: Determinacy of the Price Level, and Other Results," unpublished, Texas A\&M University, February 1990.

"A Nominal Interest Rate Rule in the Open Economy," unpublished, Texas A\&M University, August 1993.

Barro, Robert J., “Are Government Bonds Net Wealth?” Journal of Political Economy 82: 1095-

1117 (1974).

, “Interest Rate Targeting," Journal of Monetary Economics 23: 3-30 (1989).

Begg, David K.H., and Badrul Haque, “A Nominal Interest Rate Rule and Price Level Indeterminacy Reconsidered," Greek Economic Review 6: 31 -46 (1984).

Bergin, Paul R., "Fiscal Restrictions in a Currency Union: Further Lessons on the Interactions of Monetary and Fiscal Policies," unpublished, Yale University, undated [1995].

Blinder, Alan S., and Robert M. Solow, "Does Fiscal Policy Still Matter? A Reply," Journal of Monetary Economics 2: $501-510$ (1976).

Boyd, John H. III, and Michael Dotsey, "Interest Rate Rules and Nominal Determinacy," unpublished, Univ. of Rochester, February 1994.

Brock, William A.., "Money and Growth: The Case of Long-Run Perfect Foresight," International Economic Review 15: $750-777$ (1974).

, “A Simple Perfect Foresight Monetary Rule," Journal of Monetary Economics 1:133150 (1975).

Brunner, Karl, and Allan H. Meltzer, “An Aggregative Theory for a Closed Economy," in J.L. Stein, ed., Monetarism, Amsterdam: North-Holland, 1976.

Bryant, John and Neil Wallace, "The Inefficiency of Interest-Bearing National Debt," Journal of Political Economy 87: 365-381 (1979).

Cagan, Phillip, "The Monetary Dynamics of Hyperinflation," in M. Friedman, ed., Studies in the Quantity Theory of Money, Chicago: Univ. of Chicago Press, 1956. , The Channels of Monetary Effects on Interest Rates, New York: Columbia Univ. Press, 1972.

"Regulation and the Monetary Economy," in C. Lawrence and R.P. Shay, eds., Technological Innovation, Regulation, and the Monetary Economy, Cambridge: Ballinger, 1986.

Christ, Carl, "On Fiscal and Monetary Policies and the Government Budget Constraint," American Economic Review 69: 526-538 (1979). 
Cowen, Tyler, and Randall Kroszner, Explorations in the New Monetary Economics, Oxford: Blackwell, 1994.

Diamond, Peter A., "National Debt in a Neoclassical Growth Model," American Economic Review 55: 1126-1150 (1965).

Fetter, Frank W., The Development of British Monetary Orthodoxy, 1797-1875, Cambridge: Harvard Univ. Press, 1965.

Friedman, Benjamin M., "Lessons on Monetary Policy from the 1980s," Journal of Economic Perspectives 2 (Summer): $51-72$ (1988).

Friedman, Milton, A Program for Monetary Stability, New York: Fordham Univ. Press, 1959. , "The Optimum Quantity of Money," in The Optimum Quantity of Money and Other Essays, Chicago: Aldine, 1969. , "Comments on the Critics," in R.J. Gordon, ed., Milton Friedman's Monetary Framework, Chicago: Univ. of Chicago Press, 1974. , and Anna J. Schwartz, Monetary Trends in the United States and the United Kingdom, Chicago: Univ. of Chicago Press, 1982. and , "Has Government Any Role in Money?" Journal of Monetary Economics 17: 37-62 (1986).

Goodfriend, Marvin, "Interest Rates and the Conduct of Monetary Policy," CarnegieRochester Conference Series 34: 7-30 (1991).

Hayek, Friedrich A., Denationalisation of Money, 2d ed., London: Institute of Economic Affairs, 1978.

Kaldor, Nicholas, The Scourge of Monetarism, Oxford: Oxford Univ. Press, 1982.

Kohn, Meir, "On the Differing Effects of Different Types of Inflation on the Real Rate of Interest," in M. Kohn and S.-C. Tsiang, eds., Finance Constraints, Expectations, and Macroeconomics, Oxford: Oxford Univ. Press, 1988.

Leeper, Eric, "Equilibria Under 'Active' and 'Passive' Monetary Policies," Journal of Monetary Economics 27: 129-147 (1991).

Mankiw, N. Gregory, "The Optimal Collection of Seignorage: Theory and Evidence," Journal of Monetary Economics 20: 327-341 (1987).

McCallum, Bennett T., "Price Level Determinacy with an Interest Rate Policy Rule and Rational Expectations," Journal of Monetary Economics 8: 319-329 (1981a). "Monetarist Principles and the Money Stock Growth Rule," American Economic Review 71(2): 134-138 (1981b). , “Are Bond-Financed Deficits Inflationary? A Ricardian Analysis," Journal of Political Economy 92: 123-135 (1984). 
"Some Issues Concerning Interest Rate Pegging, Price Level Determinacy, and the Real Bills Doctrine," Journal of Monetary Economics 17: 135-160 (1986). , Monetary Economics: Theory and Policy, New York: Macmillan, 1989.

Obstfeld, Maurice, and Kenneth Rogoff, "Speculative Hyperinflations in Maximizing Models: Can We Rule Them Out?" Journal of Political Economy 91: 675-687 (1983). Patinkin, Don, "Financial Intermediaries and the Logical Structure of Monetary Theory: A Review Article," American Economic Review 51: 95-116 (1961). , Money, Interest and Prices, 2d. ed., New York: Harper and Row, 1965. "Money and Wealth: A Review Article," Journal of Economic Literature 7: 1140-1160 (1969).

Santos, Manuel S., and Michael Woodford, "Rational Asset Pricing Bubbles," Centro de Investigacion Economica, ITAM, Mexico City, working paper no. 93.02, November 1993.

Sargent, Thomas J., "The Ends of Four Big Inflations," in R.E. Hall, ed., Inflation, Chicago: Univ. of Chicago Press, 1982. "Reaganomics and Credibility," in A. Ando et al, eds., Monetary Policy, Cambridge: M.I.T. Press, 1985. [Reprinted as chap. 3, Rational Expectations and Inflation, 2d ed., New York: HarperCollins College Pubs., 1993.] Macroeconomic Theory, 2d ed., San Diego: Academic Press, 1987a. Dynamic Macroeconomic Theory, Cambridge: Harvard Univ. Press, $1987 \mathrm{~b}$. and Neil Wallace, "'Rational' Expectations, the Optimal Monetary Instrument, and the Optimal Money Supply Rule," Journal of Political Economy 83: 241-254 (1975). and "Some Unpleasant Monetarist Arithmetic," Quarterly Review,

Federal Reserve Bank of Minneapolis, Fall 1981. [Reprinted as chap. 5, Rational Expectations and Inflation, 2d ed., New York: HarperCollins College Pubs., 1993.] and , “The Real Bills Doctrine versus the Quantity Theory: A

Reconsideration," Joumal of Political Economy 90: 1212-1236 (1982).

Scarth, William M., "Rational Expectations and the Instability of Bond-financing," Economic Letters 6: 321-327 (1980).

Shell, Karl, "Notes on the Economics of Infinity," Journal of Political Economy 79: 1002-1011 (1971).

Sidrauski, Miguel, "Rational Choice and Patterns of Growth in a Monetary Economy," American Economic Review 57(2): 534-544 (1967).

Sims, Christopher A., "A Simple Model for the Determination of the Price Level and the Interaction of Monetary and Fiscal Policy," Economic Theory 4: 381 -399 (1994). Sweeney, Richard J., Wealth Effects and Monetary Theory, Oxford: Basil Blackwell, 1988. 
Tobin, James, "Friedman's Theoretical Framework," in R.J. Gordon, ed., Milton Friedman's Monetary Framework, Chicago: Univ. of Chicago Press, 1974.

Turnovsky, Stephen J., Macroeconomic Analysis and Stabilization Policies, Cambridge: Cambridge Univ. Press, 1977.

Webb, Steven B., Hyperinflation and Stabilization in Weimar Germany, New York: Oxford Univ. Press, 1989.

Woodford, Michael, "The Optimum Quantity of Money," in B. Friedman and F.H. Hahn, eds., Handbook of Monetary Economics, vol. II, Amsterdam: North-Holland, 1990. "Monetary Policy and Price Level Determinacy in a Cash-in-Advance Economy," Economic Theory 4: 345-380 (1994). 